\title{
Regulatory Property: The New IP
}

\author{
Robin Feldman ${ }^{*}$
}

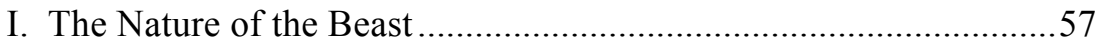

A. Marketing Rights — Quasi-Patents .....................................59

B. Data Rights - Quasi Trade Secrets....................................61

C. Tradeable Rights - Quasi Property ......................................62

II. History and Taxonomy of Regulatory Property ..............................65

A. Regulatory Property with the Creation of the Generics

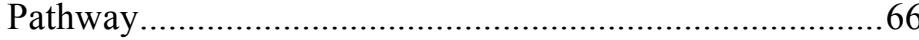

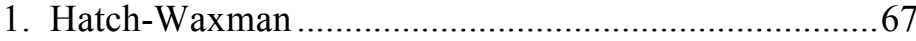

a. Six-Month Marketing Right for Generics ...............69

b. Five-Year (or Four-Year) Data Right for New Chemical Entities ...................................................70

c. Three-year Data Right for New Clinical Studies ....72

d. The Hatch-Waxman Data Rights in General ...........72

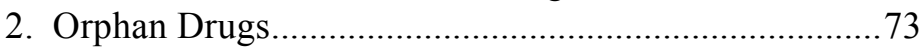

a. Logic and Structure of the Orphan Drug Act..........74

B. Regulatory Property with the Affordable Care Act..............80

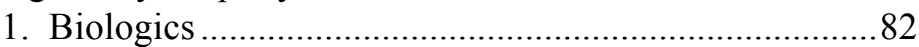

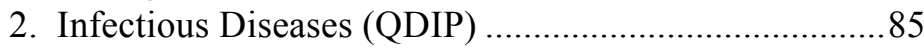

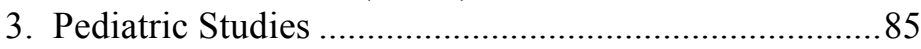

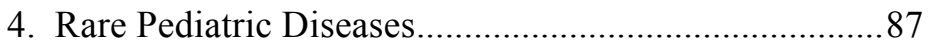

C. Proliferation-Beyond Passage of the Major Generic

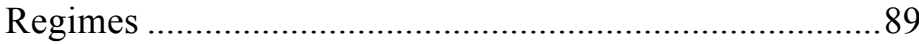

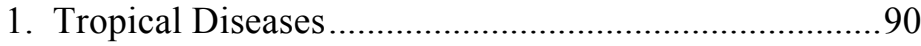

2. Unapproved Drugs ......................................................92

3. The Trans-Pacific Partnership ......................................93

4. Proposals: Abuse-Deterrent Opioids, Combination Therapies, Dormant Therapies, Diagnostic Tests ........95

III. Concepts for a Unified Whole ....................................................97

Appendix A: Summary Chart of Regulatory Property Forms ..........103

\footnotetext{
*Harry \& Lillian Hastings Professor and Director of the Institute for Innovation Law, University of California Hastings College of the Law. I wish to thank Shelley Erin Ackerman for insights into biomedical research and Connie Wang for incomparable research assistance. I also wish to thank Charles Tait Graves, David Hoffmeister, Dmitry Karshtedt, Heidi Williams and participants in the 2016 Intellectual Property Scholars Conference for comments on prior drafts.
} 
For almost thirty years, a new form of intellectual property has grown up quietly beneath the surface of societal observation. It is a set of government-granted rights that have the quintessential characteristic of intellectual property and other forms of property - that is, the right to exclude others from the territory. ${ }^{1}$

Beginning with a small piece of legislation in the early 1980 s, the system now has tentacles stretching out in many directions. It spans more than half a dozen smaller arrangements - established through individual pieces of congressional legislation or regulatory action - and confers hundreds of billions of dollars on those who can fold themselves within its various definitions. Its impact on the United States health care system, in particular, is enormous. In 2015 alone, more than 40 percent of all new drugs approved by the Federal Drug Administration (the "FDA") came through just one of these portals, with the companies collecting regulatory property rights along the way. ${ }^{2}$

Some forms of this regulatory property are quasi-patent. In the same way that patents grant the right to exclude others from making, using, or selling the invention, these types of regulatory property grant the right to exclude others from entering into the market; in many cases, for a significant period of time. Other forms are quasitrade secret. For example, trade secret prevents others from improperly accessing and using a competitor's information, although one can develop that information on one's own. Similarly, some forms of this regulatory property allow a company to exclude others from using its research data for a period of time, although others could develop the same research data on their own. Finally, some forms of this regulatory property are more like pure personal property, in that these benefits can be sold or traded on the open market.

Across the various forms, these pieces of regulatory property-or one could call them Regulatory Property - have life spans that range from six months to three, five, or even seven years. They can interact with or be added to the patent term length, and they can be added on to each other. In short, the system is extraordinarily complex and largely unnoticed, outside of the industry and its participants, although some elements occasionally surface in the press. ${ }^{3}$

Creation of this system follows no theoretical design. Sprawling and incremental, it has grown by accretion as various groups have succeeded in making good arguments that they, too, should have a benefit. Accidental property is always a dangerous form for society to create. Property created by accident lacks the thoughtful and considered exploration that provides the only hope of theoretical coherence within the legal system. When accidental property combines with a

1. See Kaiser Aetna v. United States, 444 U.S. 164, 176 (1979) (characterizing the right to exclude others as "one of the most essential sticks in the bundle of rights" that is property). See also Dolan v. City of Tigard, 512 U.S. 374, 384 (1994); Lucas v. South Carolina Coastal Council, 505 U.S. 1003, 1044 (1992); Nollan v. California Coastal Comm'n, 483 U.S. 825, 831 (1987).

2. See Michael G. Daniel et al., The Orphan Drug Act: Restoring the Mission to Rare Diseases, 39 AM. J. CliniCAL ONCOlOGY 210, 210-11 (2016); John Jenkins, U.S. FOOD AND DRUG ADMIN., CDER Approved Many Innovative Drugs in 2014, FDA VOICE (Jan. 14, 2015), available at https://perma.cc/4D5Y-JDDU.

3. See, e.g., Ted M. Burns et al., Editorial by Concerned Physicians: Unintended Effect of the Orphan Drug Act on the Potential Cost of 3,4-Diaminopyridine, 53 MusCle NeRVE 165, 166-67 (2016). 
system that is largely hidden from view, the danger intensifies.

Intellectual property rights that are hidden from view risk undermining the basic theoretical premise of the U.S. intellectual property system. Our British ancestors may have granted letters patent as private favors for those who could curry them, but not the United States. This nation's intellectual property system-particularly the patent system-is firmly rooted in notions of neutral requirements for what constitutes a sufficient contribution to society that one can receive rights for limited times and limited purposes. A hidden labyrinth of regulatory property, however, could easily become a system of private bills, in which individual companies are able to bargain for favors in a way that is hidden from public view. And there are certainly scattered examples that have that flavor. For example, the threshold level for one of the forms of regulatory property - orphan drug rights - was an arbitrary number based on the estimated prevalence of narcolepsy and multiple sclerosis over thirty years ago. ${ }^{4}$ In other words, a remarkably powerful form of regulatory property was designed in a way that ensured two particular drugs would fit.

As regulatory property plays an increasingly important role in innovation and in society, it is essential to recognize all of its various tendrils as a single system-a new form of property within the intellectual property domain. Treating regulatory property in its rightful place among the pantheon of intellectual property rights allows appropriate analysis of the interactions among these powerful forces. It isn't just a matter of labeling these phenomena as forms of property. It is a matter of understanding and making sense out of them as a coherent whole, as well as making sense of how they interact with other types of rights to exclude, such as patent and trade secret.

To frame the conversation, the title of this article references one of the most influential articles of the last century, ${ }^{5}$ The New Property, by Charles Reich. Concerned about the rise of the regulatory state, Reich argued that the various permissions and benefits conferred by the government should be understood as forms of property. ${ }^{6}$ Reich was worried about protecting those who receive the benefits from being bullied by the government. He called for benefit recipients to have small sovereign islands of their own, ${ }^{7}$ that is, protection against the encroaching power of the government that may be exercised in the process of granting or withholding of benefits. $^{8}$

While Reich was worried about protecting those who obtain benefits, this Article below is concerned about the rest of society. When government creates this type of quasi-property, along with its surrounding islands of protection, what geologic territory is left for the remainder of its citizens?

4. See Dep'T of Health AND Human Servs., infra note 53, at 4.

5. David A. Super, A New New Property, 113 ColuM. L. REV. 1773, 1779 (2013).

6. Charles Reich, The New Property, 73 YALE L.J. 733, 733 (1964).

7. See id. at 774 (noting that "[t]he great error of the public interest state is that it assumes an identity between the public interest and the interest of the majority").

8. Reich's article led to the development of due process rights for those who receive government benefits. See Super, supra note 5, at 1780 (discussing Goldberg v. Kelly, 397 U.S. 254 (1970) which relied on Reich to recognize welfare benefits as property interests protected by the due process clause). 
Consider the general construct of granting intellectual property rights, such as patents. From the activities that would ordinarily be enjoyed by all, the government removes some and appropriates them to the benefit of the few, in the hopes that the strategy will redound to the advantage of everyone. ${ }^{9}$ The same is true for Regulatory Property, and one cannot properly evaluate whether those benefits are accomplishing their intended goals without understanding the system as a whole and understanding its interactions with other forms of intellectual property

Although one could argue over whether regulatory property should exist, society rarely succeeds in turning back the tide. Thus, the better part of valor would be to make sense of the system that has grown around us, understanding and enhancing its positive aspects while cabining its negative ones. Only if we contemplate regulatory property as a single, unified organism, however, can we wrap our arms around it and make sense out of the whole.

To that end, Section I of this Article begins by analyzing the various forms of regulatory property ${ }^{10}$ that have emerged over the last thirty years according to their similarity to other types of intellectual property - such as patent and trade secretand to property in general. Section II then examines the emergence of this Regulatory Property, identifying the history of each one and creating the first complete accounting of all of them. This Section also demonstrates the relationship between the myriad congressional bills creating these regulatory properties and passage of major legislation that the pharmaceutical industry resisted. In other words, Congress appears to have responded repeatedly to pharmaceutical industry displeasure by passing scattered bills that would grant new forms of Regulatory Property.

If Regulatory Property should be understood as a unified system, one must have some theoretical grounding for its existence. Without a coherent construct, there is no way to intelligently shape its development and test its success. Thus, Section III of the paper sets out a general theoretical framework for the type of regulatory property that has emerged. This Section also explores a series of benchmarks to use in establishing Regulatory Property, describing the logic for these benchmarks, and tests the current forms of Regulatory Property against these measures. The benchmarks include: (1) minimizing overlap with other forms of intellectual property; (2) ensuring that the system is capable of stimulating results, and that those results are desirable; and (3) ensuring that there is a metric for measuring outcomes in relationship to goals. With these and other perspectives, society has an opportunity to think critically and cohesively about the new form of intellectual property that has developed incrementally over the last several decades.

The Regulatory Property that has emerged so far falls within the life science industry. That is understandable. The FDA's all encompassing approval scheme and regulatory system has provided a perfect vehicle for the creation and

9. Robin Feldman, Intellectual Property Wrongs, 18 STAN. J.L. Bus. \& Fin. 310, 318 (2013).

10. This Article's use of the term Regulatory Property is in contrast to the use of the term by Anna Laakmann. Laakmann uses the term to refer to information necessary to satisfy a regulatory standard, and appropriate to include in a submission to a regulatory agency. See Anna Laakmann, A Property Theory of Medical Innovation, 56 JURIMETRICS J. 117, 119 (2016). 
dissemination of Regulatory Property. The lessons, however, are widely applicable to other innovative industries. As newcomers in industries such as transportation (think Uber and Lyft), hospitality (think Airbnb and Villas), ${ }^{11}$ and domestic and construction services (think TaskRabbit) press the boundaries of creativity up against regulatory networks, government actors may be tempted to create forms of Regulatory Property related to these innovations, in the hopes of incentivizing innovative entrants as well as placating existing industry players. For example, local, state, or federal authorities might try to attract an industry, such as solar energy innovation, devising benefits for new entrants balanced against protections for existing energy industries. Such is the story of the creation of Regulatory Property for the life science industry, and it is one that easily could be replicated.

It is also a story with echoes in the international arena. Various aspects of these rights have tentacles that now reach into the European Union, the North American Free Trade Agreement, and most recently, the Trans-Pacific Partnership. ${ }^{12}$ Thus, after thirty years, it is more than time to think comprehensively about this new form of intellectual property rights, a regime that lies entwined throughout our system.

\section{THE NATURE OF THE BEAST}

There is nothing sacred about the current contours of intellectual property as a legal discipline. Although patents and copyrights trace their heritage back to the Constitution, ${ }^{13}$ the concept of intellectual property as a unified field developed more recently, emerging in its current incarnation largely in the $1980 \mathrm{~s} .{ }^{14}$ In fact, one can see its emergence through a Google Ngrams graph, a search result that charts the frequency with which a particular term appears in books across a designated time period. ${ }^{15}$

11. Stephanie Rosenbloom, Giving Airbnb a Run for Its Money, N.Y. TIMES (Feb. 15, 2015), available at https://perma.cc/M22G-MAF5.

12. See Jerome H. Reichman, Rethinking the Role of Clinical Trial Data in International Intellectual Property Law: The Case for a Public Goods Approach, 13 MARQ. INTELL. PROP. L. ReV. 1, 6-8 (2009) (discussing the spread of protection for data rights, described as clinical trial data, through international, regional, and bilateral trade agreements); see also Brook K. Baker, Trans-Pacific Partnership Provisions in Intellectual Property, Transparency, and Investment Chapters Threaten Access to Medicines in the US and Elsewhere, 13 PLOS MED. 3, 3-4 (2016) (explaining TPP provisions requiring countries to adopt data and marketing exclusivity restrictions for pharmaceutical products involving new chemical entities and for biologics).

13. See U.S. CONST. art. I, § 8, cl. 8 (authorizing Congress to "promote the Progress of Science and useful Arts, by securing for limited Times to Authors and Inventors the exclusive Right to their respective Writings and Discoveries").

14. See ABA Section of Antitrust LaW, Intellectual Property and Antitrust HANDBOOK (2007) (discussing the modern era of intellectual property, beginning in the 1980s); see also Benjamin Coriat \& Olivier Weinstein, Intellectual Property Right Regimes, Firms, and the Commodification of Knowledge, 5 CLPE RES. PAPER 3, 12-14 (2009) (outlining the emergence of a new intellectual property regime in the 1980s accompanying the rise of finance-led capitalism); see also William M. LANDES \& RichaRd POSNER, THE POLITICAL ECONOMY OF INTELLECTUAL PROPERTY LAW (2004) (describing growth in intellectual property protection in the 1980s and 1990s).

15. For an explanation of Google Ngrams, see https://perma.cc/32HW-KUYG. 
Figure 1. ${ }^{16}$

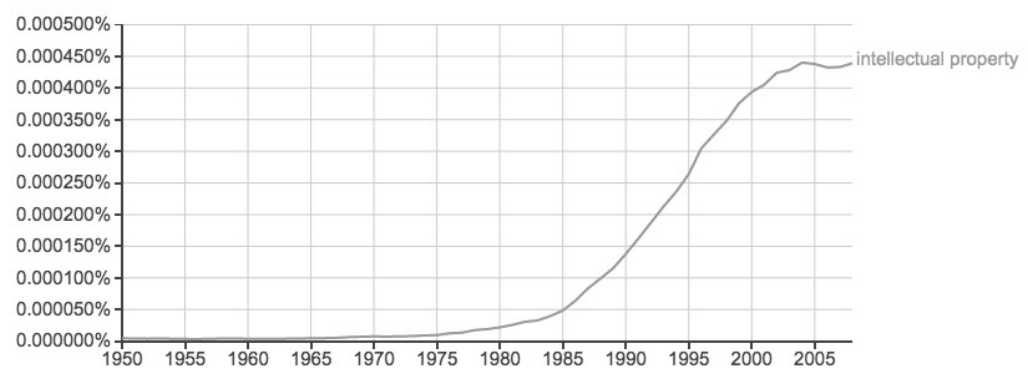

As the graph suggests, the designation of intellectual property as a unified field did not appear with any frequency until the 1980s. As described in Section II below, Regulatory Property emerged during the same time period, although it has remained strangely absent from conventional discussion. Rather, intellectual property is defined as including only copyright, patent, trademark, and trade secret. ${ }^{17}$

Although the term "intellectual property" harkens back to traditional notions of property within the legal system, the characteristics of property and intellectual property diverge considerably. To take a simple example, if I plant corn on an ordinary piece of land, you cannot plant corn there as well, and even my own ability to plant corn will diminish over time as the nutrients in the land are depleted. In contrast, you and I can both sing a song at the same time, and we can sing it over and over again without depleting much more than the patience of our families. ${ }^{18}$

Despite valiant efforts across time to equate some forms of intellectual property with property such as land, intellectual property defies that categorization. ${ }^{19}$ It is

16. To generate this graph, see https://perma.cc/2JTQ-NN8P. I thank Carl Shapiro's presentation at the American Economic Association 2016 Annual Meeting for the idea of using Google Ngrams to map the use of various intellectual property terms.

17. Donald S. Chisum et al., Understanding Intellectual Property LaW $\S 1 \mathrm{~B}$ (3d ed. 2015) (describing patents, trade secrets, copyright, and trademarks as the four major intellectual property rights).

18. For less lighthearted discussions of the non-rivalrous nature of intellectual property, including the economic implications of zero marginal cost of production of intellectual property, see, e.g., Kenneth J. Arrow, Economic Welfare and the Allocation of Resources for Invention, in THE RATE AND DIRECTION OF INVENTIVE ACTIVITY: ECONOMIC AND SOCIAL FACTORS 609 (Richard Nelson, ed., 1962) (presenting this argument); Harold Demsetz, Information and Efficiency: Another Viewpoint, 12 J.L. \& ECON. 1 (responding to Arrow); see also Amy Kapczynski, The Cost of Price: Why and How to Get Beyond Intellectual Property Internalism, 59 UCLA L. REV. 970, $974-76$ (comparing and contrasting Arrow and Demsetz).

19. See Robin Feldman, Rethinking Patent LaW 9-33 (2012) (exploring the ways in which patents are not analogous to land); John F. Duffy, Rethinking the Prospect Theory of Patents, 71 U. CHI. L. REV. (2004) (describing Edmund Kitch's comparison of patents to mineral claims for land and noting that while Kitch's theory represents one of the most significant efforts to integrate intellectual property with property rights theory, it has been criticized as without foundation and divorced from reality); see also Teva Pharm. USA, Inc., et. al. v. Sandoz, Inc., 135 S. Ct. 831, 848 (2015) (Thomas, J. dissenting) (explaining that the Anglo-American legal tradition has long distinguished between core private rights 
neither tangible nor finite in nature, beyond the duration of the government-granted legal right. ${ }^{20}$ Moreover, the boundaries of intellectual property must be set in the face of rapidly changing knowledge and meaning, as inventions and creations are compared to things that did not exist when protected invention or work was created. ${ }^{21}$ Thus, the process of creating efficient divisions for things of such an unbounded nature will involve quite different considerations from the process for efficient division of the more bounded, regardless of the meandering path that the bounded may take. ${ }^{22}$

Nevertheless, the various legal rights for intellectual property share significant characteristics with rights related to property, including the right to exclude others. ${ }^{23}$ These will become important in comparing intellectual property rights with the emerging Regulatory Property.

As described in Section II below, ${ }^{24}$ most forms of Regulatory Property were created by Congress and operate through the FDA. Although the different forms may combine several types of rights, the rights generally fall into three baskets. The baskets include marketing rights, data rights, and tradeable rights like priority review. Most of these look like revised forms of other intellectual property rights. They have the feel of having been created by market actors who, after living with certain types of intellectual property and regulatory systems, adjusted existing forms to better fit their needs.

\section{A. Marketing Rights-Quasi-Patents}

The first basket consists of marketing rights, that is, all others are excluded from receiving permission to market the product for a period of time. For example, if a drug company approved by the FDA contains a new chemical entity, the FDA cannot grant approval for any other company to market a drug containing the same chemical entity for five years.

Marketing rights can be analogized to patent rights. ${ }^{25}$ With patents, one has the

such as those related to land and other privileges, and that patents fall outside those core private rights); Caleb Nelson, Adjudication in the Political Branches, 107 COLUM. L. REV. 559, 567 (2007) (cited in the Teva dissent); Robin Feldman, Federalism, First Amendment \& Patents: The Fraud Fallacy, 17 Colum. SCI. \& TECH. L. REV. 30, 71-72 (2016) (contrasting the respect for real property evidenced in Constitutional language and history with what is reflected in the Constitution's intellectual property clause).

20. FeldMAN, supra note 19, at 32; see also Reich, supra note 6, at 739 (noting that while wealth and value are created by culture and society, property is a creation of law in that a man who has property has certain legal rights with respect to an item of wealth).

21. See FELDMAN, supra note 19, at 3.

22. See id. at 32 .

23. Despite frequent slips of the tongue by courts and commentators, patents do not grant any positive rights, but only the right to exclude. For examples of such errors, see, e.g., In re Indep. Serv. Orgs. Antitrust Litig., 203 F.3d 1325 (Fed. Cir. 2000); Brief for Respondent, at 34, Ill. Tool Works Inc. v. Indep. Ink, Inc., 547 U.S. 28 (2006) (No. 04-1329); Henry C. Su, Intellectual Property Rights and Market Power, 877 PLI Patents, Copyrights, Trademarks, \& Literary Property Course Handbook Ser. 135, 144 n.22 (2006).

24. See Section II, infra.

25. See infra note 50 , for authors who have referred to various types of the benefits in regulatory 
right to exclude others from making, using, or selling the patented invention. With marketing rights, others are similarly excluded from selling the product on the market.

Although marketing rights are focused on selling in the market, they are somewhat stronger than ordinary patent rights. First, patent rights are not self-executing. No district attorney, no federal agency will step forward to champion a patent holder's rights. If a patent holder wishes to exercise its right to exclude someone from selling the product, the patent holder must bring a lawsuit. In contrast, when a company receives marketing rights, the FDA enforces those rights by refusing to grant approval to any other company. ${ }^{26}$

The second difference relates to a popular misconception about the power of patent rights. For those who are not patent mavens, this is a good moment to hold onto your hats. It would be easy to assume that a patent grants the right to a circle of territory, and all others are excluded from that circle. Such is not the case. The patent does, indeed, grant the right to exclude others from a circle of territory, but that does not mean the patent holder controls the entire circle alone. Others have may have exclusion rights to parts of the same circle.

Consider the following example, adapted from discoveries at the University of Rochester. $^{27}$ An inventor obtains a patent on a chemical dye for coloring candy a bright shade of blue. Under what is known as the one embodiment rule, the patent holder who identifies one use for the chemical can claim rights to all uses of the chemical. $^{28}$ A later inventor discovers that the dye is useful for treating spinal cord injuries. The second inventor can receive a patent on the new use of the existing chemical for spinal cord research and treatment. ${ }^{29}$ At this point, the first inventor has the right to exclude everyone from using the chemical for anything (including spinal cord research and treatment); the second inventor has the right to exclude everyone from using the chemical for spinal cord research and treatment; and neither can use the chemical for spinal cord research and treatment without the permission of the

rights as patent-like.

26. For a discussion of this aspect of FDA marketing exclusivities in the context of Hohfeldian immunities and disabilities, see Yaniv Heled, Patents v. Statutory Exclusivities in Biological Pharmaceuticals-Do We Really Need Both?, 18 Mich. TeleCOMM. \& TECH. L. REV. 419, 431 (2012).

27. See FELDMAN, supra note 19, at 24 (describing these circumstances and the patent example and sources in further detail); see also Same Blue Dye in M\&Ms Linked to Reducing Spinal Injury, CNN (July 28, 2009), https://perma.cc/6PAK-G4MP (describing work in mice at the University of Rochester, demonstrating that the blue dye used in M\&M candy appears to reduce damage caused by spinal cord injuries when injected into the spinal cord).

28. See, e.g., Schering Corp. v. Gilbert, 153 F.2d 428, 432 (2d Cir. 1946); Maurer v. Dickerson, 113 F. 870, 874 (3d Cir. 1902) (finding "that the claim is not restricted to the product made by the described process, but covers the chemical individual, however produced"); Utility Examination Guidelines, 66 Fed. Reg. 1092-02, 1095 (Jan. 5, 2001) (noting that "[a] patent on a composition gives exclusive rights to the composition for a limited time, even if the inventor disclosed only a single use"); see also Amgen, Inc. v. Chugai Pharm. Co., 927 F.2d 1200, 1213 (Fed. Cir. 1991) (noting that it is not necessary that a patent application test all embodiments of an invention); In re Angstadt, 537 F.2d 498, 503 (C.C.P.A. 1976) (same).

29. 35 U.S.C. $\$ 101$ ("or any new and useful improvement thereof"). See, e.g., Allegheny Drop Forge Co. v. Portec Inc., 541 F.2d 383 (3d Cir. 1976) ("A new use for an old process or product is patentable if the new use or application is itself not 'obvious' to one skilled in the art."). 
other. $^{30}$ This is the case of overlapping rights, and although most patents do not overlap, it is a limitation of the power of the patent. In short, the patent holder does, indeed, obtain the right to exclude others from a circle of territory. Nevertheless, others may be standing in parts of that circle with their own rights to exclude, effectively shrinking the patent holder's practical sphere of operations.

Marketing rights are different in some circumstances. When a company qualifies for marketing rights under some forms of Regulatory Property, the company gets an affirmative right to market the drug, along with rights that may operate as a blanket exclusion of all other companies for all uses. ${ }^{31}$ Unlike patent rights, therefore, you get to ensure that no others will be standing in the circle with you, and the federal government does the work of enforcing your rights.

\section{B. Data Rights-Quasi Trade Secrets}

The second category relates to data rights, in which other companies are prevented from using one's safety and efficacy data that were submitted to regulatory authorities and used as a basis for granting approval. For example, a company wishing to make a generic version of a drug will be prevented from using the original company's data for a period of time, although the generic company could conduct its own safety and efficacy trials during that time. ${ }^{32}$

The right to generate one's own safety and efficacy data, however, is unlikely to be an attractive pathway. ${ }^{33}$ Safety and efficacy trials are lengthy and expensive. Generic companies, trying to enter the market quickly and cheaply, are generally loath to follow that path. Thus, they are somewhat stronger than trade secrets. Data rights are also stronger than trade secret rights in another manner. With trade secrets, the right is lost when the information is no longer secret. ${ }^{34}$ With regulatory data rights, the right continues, regardless of whether the information is released to the public.

Data rights can be analogized to trade secrets. Under trade secret law, a company would be entitled to protect information that would give it a commercial advantage over competitors, as long as that information is not readily ascertainable to others in

30. DonAld S. Chisum, CHISUM On PATENTS, vol. 5, §16.02 (2010) ("Two patents may be valid when the second is an improvement on the first, in which event, if the second includes the first, neither of the two patentees can lawfully use the invention of the other without the other's consent." (quoting Cantrell v. Wallick, 117 U.S. 694 (1886))).

31. See infra text accompanying notes 170-181 (describing a program created in 2012 for pediatric studies that extends exclusivities, including marketing rights, for all uses and formulations of a drug); text accompanying notes 125-133 (describing ways in which marketing rights for orphan drugs operate to block valuable off-label uses of a drug, in addition to the orphan indication).

32. See John R. Thomas, The Role of Patents and Regulatory Exclusivities in Pharmaceutical Innovation, CONG. RESEARCH SERV. 4 (Jan. 7, 2013) (describing data exclusivity, or the "data package," submitted by brand-name firms and the ways in which this may be used by generic firms), available at https://perma.cc/Y8K6-2CJE.

33. See id.

34. See 1-1 Roger M. Milgrim, Milgrim on Trade Secrets $\S 1.05,2$ (2015) (noting that once information becomes publicly disclosed or readily available, it forfeits its trade secret status). 
the field. ${ }^{35}$ Competitors who developed the information on their own, however, would be free to use it.

The treatment of independent creation under trade secret law, as well as with data rights, stands in contrast to patent law. No one can use another's patented invention, even when that invention is created independently. ${ }^{36}$

Data rights are more limited than trade secrets, at least in duration. Trade secret protection essentially lasts as long as the information remains a secret. Data rights, however, are granted only for a limited period of time.

From this perspective, data rights can be analogized to a cousin of trade secret rights, non-compete clauses, in which departing employees may be prevented from working for competitors for a period of time. ${ }^{37}$ Unlike trade secret protection, noncompete clauses are for limited duration. ${ }^{38}$ They also are agnostic as to whether the information that is being protected might be secret or in the public domain. ${ }^{39}$

The data rights time period is related to a Congressional choice to require that pharmaceutical companies make their safety and efficacy data available to those who would make lower-cost versions of the drug once the patent protection ends. The data sharing system is part of a complex legislative scheme designed to get generics to market as quickly as possible and to encourage would-be generic companies to challenge weak patents in court. ${ }^{40}$ Thus, the data rights time period ensures a certain length of protection for the original drug maker's data under all circumstances, even if the generic will eventually succeed in overturning the patent.

From one perspective, one can think of data rights as a pure grant of benefits to pharmaceutical companies-given that data rights have the potential to confer protection to a drug company, even when the company's patents are invalid or expired. From another perspective, one can think of data rights as a compromise: trade secret protection would give drug company's an indefinite length of protection for their data, pure sharing would provide no data protection, and data rights provide a level of protection somewhere between the two.

\section{Tradeable Rights-Quasi Property}

The third basket of rights that may be granted with Regulatory Property relates to tradeable rights. In most cases, rights that are granted with Regulatory Property are

35. Uniform Trade Secrets Act $\S 1.4$ (1985).

36. See Kewanee Oil Co. v. Bicron Corp., 416 U.S. 470, 478 (1974) (finding that the patent right applies not only to direct copies of the subject matter, but also independent creations).

37. See Donald J. Aspelund \& JoAn E. BeCKNer, Employee Noncompetition LaW $\S 3.2$ (2016) (defining a non-compete clause as "an employment agreement whereby the employee agrees not to compete with his employer after termination of his employment for a specified period of time and in a particular area").

38. Id.

39. Charles Tait Graves, Analyzing the Non-Competition Covenant as a Category of Intellectual Property Regulation, 3 HASTINGS SCI. \& TECH. L.J. 69, 90 (noting that a departing employee is prohibited from using both trade secrets and public domain or generally known information in competition).

40. See infra text accompanying notes 59-68. See also Robin Feldman \& Evan Frondorf, Drug Wars: A New Generation of Pharmaceutical Delay, 53 HARV. J. ON LEGIS. 499 (2016) (describing in detail the mechanisms of the Hatch-Waxman Act). 
specific to the drug going through the approval process. In some cases, however, a company that engages in the desired behavior receives a right fully stripped from the drug. For example, a company that secures a tropical disease voucher receives the right to move a second drug application more quickly through the FDA review system in some form. ${ }^{41}$ The company can use that right on another one of its drugs, or it can transfer the right to another company. The ability to freely trade the right makes these benefits analogous to ordinary property rights, which, in general, enjoy the right of transfer. ${ }^{42}$

Even without an explicit right of transfer, the benefit of any Regulatory Property is a tradeable economic benefit, to some extent. One could always sell the company, transferring the economic value of the right along with it. The benefit might not transfer to another drug, but the overall economic value of the benefit from one drug transfers to the entire operation, as with any corporate asset.

Moreover, there may be more direct ways in which Regulatory Property granted to one drug can be transferred to another drug. Consider drug pricing in the context of what are known as pharmacy benefit mangers. Pharmacy benefit managers are third-party managers who negotiate pricing between pharmaceutical companies and large purchasers such as hospitals, private health insurance companies (such as Kaiser or Cigna), drugstore chains (such as Walgreen's or CVS), or government health plans (such as Medicare and Medicaid). ${ }^{43}$ A drug company like Merck will work with the pharmacy benefit manager for Kaiser; for example, to negotiate the prices Kaiser will pay on all of Merck's drugs. ${ }^{44}$ As a result, pricing in the pharmaceutical industry is no longer drug specific in many cases.

Such bulk pricing could provide the opportunity for drug companies to use the power of benefits granted in one drug to effect the pricing of other drugs. ${ }^{45}$ For example, suppose the company's drug Life Extender is facing competition from new substitutes.

41. See infra text accompanying notes 199-203.

42. But see, Robin Feldman, Whose Body Is It Anyway? Human Cells and the Strange Effects of Property and Intellectual Property Law, 63 STAN. L. REV. 1377, 1382-83 (2011) (noting that although modern property law scholars think of property as a bundle of rights with four key attributes, including the right of disposition, those rights may be circumscribed, and using medicine as an example in which the right to transfer and even to throw away may be restricted).

43. See Allison D. Garrett \& Robert Garis, Leveling the Playing Field in the Pharmacy Benefit Management Industry, 42 VAL. U. L. REV. 33, 33-80 (2007) (describing the structure of the PBM industry); see also Robert F. Atlas, The Role of PBMs in Implementing the Medicare Prescription Drug Benefit, HEALTH AFF., 504-15 (2004) (explaining the expanded role of PBMs created by the Medicare Prescription Drug, Improvement, and Modernization Act of 2003, which relies upon PBMs to administer the Medicare prescription drug benefit).

44. See Garrett \& Garis, supra note 43, at 45 (describing how drug manufacturers insist on bundling drugs and providing aggregate pricing, precluding negotiations on a drug-by-drug basis); see also FED. Trade Comm'N, Pharmacy Benefit Managers: Ownership of Mail-Order Pharmacies (Aug. 2005), https://perma.cc/T4JZ-N9UU (noting that pharmaceutical manufacturers can make "formulary payments" to PBMs to have their drug listed on a formulary or obtain a preferred spot on a formulary and can make "market-share payments" to encourage PBMs to dispense their drugs, with payment based on the quantity of drugs administered).

45. See Garrett \& Garis, supra note 43 , at $44-46$ (describing how pharmaceutical manufacturers use PBMs to increase market share for specific drugs). 
Now suppose the company has obtained Regulatory Property on another drug, SleepAid. This could be marketing rights, for example, that will keep any other company from getting approval to market SleepAid for five years. The company could offer to lower the cost of SleepAid somewhat, without fear of attracting competition for the drug, in exchange for the pharmaceutical benefit manager agreeing to keep Life Extender in the hospital's standard list of drugs that it stocks. A similar deal could be offered to insurers to get a reduced rate for the well-protected SleepAid in exchange for keeping the more vulnerable Life Extender on the insurer's formulary of approved drugs that it will either reimburse, reimburse at the lowerdeductible rate, or agree to fill without extra layers of approval. Techniques such as these could be particularly effective against younger market entrants who do not have as many goodies in their bags with which to bargain. ${ }^{46}$ In this way, the drug company can transfer the benefit it has received from Regulatory Property on one drug to the benefit of another drug. Thus, while some Regulatory Property is explicitly tradeable, the benefit of any Regulatory Property may be transferrable in more subtle ways.

The transferability of Regulatory Property highlights the importance of contemplating these rights as a whole, as well as understanding the way in which they interact with other forms of intellectual property. The Regulatory Property benefits described above can be combined with other forms of intellectual property, such as patents, to extend or enhance the benefits that would be gained under traditional intellectual property alone. ${ }^{47}$ For example, a company that receives marketing rights for an orphan drug can use those rights to exclude other entrants from the market, even if the company's patents have expired. Those marketing rights can be added on to other forms of exclusivity, such as pediatric exclusivity. In other words, the various forms of Regulatory Property can be added to each other and to patents to extend a company's ability to ensure protected market space.

The following section will introduce the various forms of Regulatory Property. Each has been created in the hopes of incentivizing certain behaviors that society deems valuable. Implicit or explicit in each is the supposition that ordinary market incentives would be insufficient or that market failures would operate to prevent the desired outcome without the incentive that the Regulatory Property would provide. ${ }^{48}$

46. For a discussion of the ways in which other types of bulk pricing schemes can be used to deter market entrants, see Robin Feldman, Defensive Leveraging in Antitrust, 87 GEO. L.J. 2079 (1999).

47. See, e.g., Renu Lal, Patents \& Exclusivity, FoOd \& Drug AdMIN. CTR. FOR DRUG Evaluation And Res. Small Bus. And Industry Assistance Chrons. 1, 3 (May 19, 2015), https://perma.cc/CZA5-9PR6 (explaining that the six-month exclusivity for first generic filers may run concurrently with patents).

48. See, e.g., Rebecca S. Eisenberg, The Role of the FDA in Innovation Policy, 13 MicH. TELECOMM. TECH. L. REV. 345, 347-48 (describing how deficiencies in the patent system have led FDAgranted exclusivities to become an increasingly important incentive for innovation); Valérie Junod, Drug Marketing Exclusivity Under United States and European Union Law, 59 FOOD \& DRUG L.J. 479, 481-85 (2004) (characterizing marketing exclusivity as a solution to cases of market failure, such as when a pharmaceutical company discovers that a potentially promising drug in development cannot be patented); Maxwell R. Morgan, Regulation of Innovation under Follow-On Biologics Legislation: FDA Exclusivity as an Efficient Incentive Mechanism, 11 COLUM. SCI. \& TECH. L. REV. 93, 100-06 (2010) (arguing in favor of FDA-administered exclusivities as a mean of promoting biologics innovation without the pitfalls of the 
In some cases, the desired behavior is the creation of lower cost generic or biosimilar drugs. In others, the goal is to challenge weak patents. In others, the desired behavior is investing in certain types of drug testing or drug creation when market incentives might not be sufficiently strong. Society cannot hope to evaluate the effectiveness of these initiatives or to measure them against externalities without understanding the system as a whole and examining the ways in which Regulatory Property interacts with other types of rights.

\section{HISTORY AND TAXONOMY OF REGULATORY PROPERTY}

The Regulatory Property described in this article first emerged in the $1980 \mathrm{~s}$, ${ }^{49}$ with newer forms appearing periodically over the subsequent thirty years. Although the term "Intellectual Property" also emerged during the early 1980s, Regulatory Property generally has been left out of the broader intellectual property calculus. ${ }^{50}$

It is challenging, if not downright impossible, to find a clear and comprehensive explanation in any given location of all of the forms of Regulatory Property. ${ }^{51}$ What

traditional patent system).

49. See Thomas, supra note 32 .

50. When they are grouped together, although often incompletely, they are described as regulatory exclusivities or named by reference to some subtype of right, such as data exclusivity. See, e.g., Thomas, supra note 32 (using the term "regulatory exclusivities"); Lal, supra note 47; Erica Lietzan, The Myths of Data Exclusivity, 20 LEWIS \& ClARK L. REV. 91, 104 (2015) (focusing on "data exclusivity"). Some scholars and commentators have referred in passing to these benefits as patent-like or a form of intellectual property. See Lietzan, supra at 104 (noting that some writers have described data exclusivity as patentlike or a sub-type of intellectual property); see also Daniel J. Hemel \& Lisa L. Ouellette, Beyond the Patents-Prizes Debate, 92 TEX. L. REV. 303, 309, 316-25 (2013) (noting that the authors group regulatory exclusivities and patents together as ex post, market-set, user pays mechanisms); Thomas, supra note 32, at 12-13 (describing regulatory exclusivities as a more recent form of intellectual property); see also Eisenberg, supra note 48 at 360 (describing "FDA administered proprietary rights in regulatory data"); Robert Alan Hess, Excavating Treasure from the Amber of the Prior Art: Why the Public Benefit Doctrine is Ill-Suited to the Pharmaceutical Sciences, 66 FOOD \& DRUG L.J. 105 (2011) (referring to "pseudopatents"); JAY THOMAS, Toward a Theory of Regulatory Exclusivities, in PATENT LAW IN GLOBAL PERSPECTIVE 345 (Ruth L. Okediji \& Margo A. Bagley eds. Oxford 2014) (noting that regulatory exclusivities can "fairly be described as the newest form of intellectual property"); Trudo Lemmens \& Candice Telfer, Access to Information and the Right to Health: The Human Rights Case for Clinical Trials Transparency, 38 AM. J.L. \& MED. 63, 84-85 (2012) (referring to data exclusivities as "patent-style protection").

51. See Thomas, supra note 32 , at 4 (noting that regulatory exclusivities are not subject to a standard terminology and that regrettably some commentators use terms such as "statutory exclusivity," "data protection," and "marketing exclusivity" synonymously with the term "regulatory exclusivity"); Lietzan, supra note 50, at 12-13 (noting confusing uses of various terms). One particularly useful document can be found at the FDA website, which lists five forms of what it calls "exclusivity." This listing does not include all of Regulatory Property, omitting the various tradeable rights, and includes various types of data rights such as rights related to New Chemical Entities within what it describes as "marketing rights granted by the FDA upon approval of the drug." See Lal, supra note 47. Other excellent sources include some, but not all of the various forms described here. See e.g., Yaniv Heled, Regulatory Competitive Shelters, 76 OHIO ST. L.J. 299 (2015) (presenting a comprehensive taxonomy, but one that does not include the rare pediatric vouchers and the tropical disease vouchers); Gregory Dolin, Exclusivity Without Patents: The New Frontier of FDA Regulation for Genetic Materials, 98 IOWA L. REV. 1399, 1448-53 (describing new chemical entity rights but not the similar new clinical studies rights); Aaron S. Kesselheim, Using Market-Exclusivity Incentives to Promote Pharmaceutical Innovation, 363 N. ENGL. J. MED. 1855 (2010) (discussing a number of regulatory exclusivity benefits but not including new 
is even more challenging, however, is to find any inkling of the historic context in which they emerged-and that history is significant. Many of the forms of Regulatory Property were created during periods of time when Congress passed legislation that the pharmaceutical industry vigorously opposed. ${ }^{52}$ In other words, repeatedly over the last thirty years, legislators have approved the creation of some form of Regulatory Property in the same Congress in which the legislators garnered enough votes to pass major laws that the industry resisted.

Other changes have occurred across the thirty years. Congress has amended the various Acts in ways that expanded, or occasionally contracted, the reach of the Regulatory Property that had been created. ${ }^{53}$ Similarly, courts and regulatory authorities have, at times, re-interpreted aspects of the statute to create a broader reach for Regulatory Property rights holders. ${ }^{54}$ Nevertheless, the trend of creation of Regulatory Property in conjunction with swallowing a bitter bill is striking.

To highlight this history, the Article will introduce the forms of Regulatory Property grouped together in their historic context. In addition, Appendix A includes a chart for visualizing all of the forms of Regulatory Property and their relationships.

\section{A. Regulatory Property With the Creation of the Generics PathWay}

Regulatory Property was born with the passage of the famous Hatch-Waxman Act, which created the modern pathway for approval of generic drugs. Several forms passed as part of the massive Hatch-Waxman Act itself in 1983. These include marketing rights for the first generic company, data rights for new chemical entities, and various forms of data rights for new clinical studies. ${ }^{55}$

In the same Congress, legislators passed a bill related to marketing rights for what is known as "orphan drugs." Although the original Orphan Drug Act had been

chemical entities, new clinical studies, biologic interchangeables, and QDIP exclusivities); see Thomas, supra note 32 (one of the more exhaustive lists but not discussing tropical disease vouchers); Emily Morris, Patent Exclusivity Versus Regulatory Exclusivity Under the Hatch-Waxman Act 34-35 (Ind. Univ. Robert H. McKinney Sch. Of Law, Research Paper No. 2012-30), http://papers.ssrn.com/sol3/papers.cfm?abstract_id=2185180 (focusing on Hatch-Waxman provisions, and thus, no discussion of biologic interchangeables, QDIP exclusivities, and tropical disease vouchers).

52. See infra text accompanying notes 70, 138-139.

53. For example, although the Orphan Drug Act passed in 1983, it was amended in 1984 (loosened the definition of rare disease), 1985 (extended to patentable as well as unpatentable drugs), 1988 (required applicants to apply for orphan drug status before applying for marketing approval), and 1997 (application user fees exempted). See Office of Inspector Gen., DeP'T of Health And Human ServS., The Orphan Drug Act: Implementation and Impact, 4 (May 2001), https://perma.cc/8PFF-L5KW.

54. David Hoffmeister, et al., Top FDA Developments of 2015 and Predictions for 2016, LAW360 (Jan. 11, 2016), https://perma.cc/J234-XR57 (noting that the FDA, in response to actions related to Amarin's drug Vascepa, in 2015 changed its interpretation of New Chemical Entity to say that drugs which contain, as their sole active ingredient, a single component of a previously approved multicomponent mixture are entitled to 5 year exclusivity); see also Vern Norviel, et al., Amarin Decision Opens Door to Longer Exclusivity Periods, LAW360 (June 12, 2015, 2:06 PM), available at http://www.law360.com/articles/665186/amarin-decision-opens-door-to-longer-exclusivity-periods.

55. See infra, text accompanying notes 65-81.

56. See David Loughnot, Potential Interactions of the Orphan Drug Act and Pharmacogenomics: A Flood of Orphan Drugs and Abuses?, 31 AM. J.L. \& MED. 365, 367-68 (2005) (explaining the origins of the term "orphan drugs"). 
signed into law during the prior Congress, the Act did not stimulate much interest until the changes made during the Hatch-Waxman Congress. ${ }^{57}$ In short, the 19831984 Congress set the stage for the system of Regulatory Property, along with its central role in modern drug development.

Together, the Regulatory Property created through the Hatch-Waxman Act and the 1984 Orphan Drug Act Amendments account for a remarkable portion of the medicines developed by the pharmaceutical industry, approved by the FDA, and available on the market today. For example, orphan drugs accounted for 41 percent of drugs approved by the FDA in $2014 .^{58}$

\section{Hatch-Waxman}

The Hatch-Waxman Act, which the President signed into law in 1984, created the modern pathway for expedited approval of generic drugs. ${ }^{59}$ The law reflects the desire to bring lower-priced drugs to consumers as quickly as possible after the patents expire, balanced against the need to ensure adequate incentives for pharmaceutical research and development. Specifically, the patent system provides a twenty-year right to exclude for the invention of new drugs that are sufficiently innovative to receive patent protection. ${ }^{60}$ Patent theory holds that during this time, the drug company should be able to recoup its investment in the discovery and development of the drug through the elevated pricing that can occur without direct competitors in the market. When the patent expires, however, other drug makers should be able to enter the market and drive down the price of the drug.

What works in patent theory does not always work in practice. Those who would

57. See id. at 375 (explaining reasons why drug companies were reluctant to file orphan drug applications with the FDA until the 1984 amendments to the Act).

58. See Daniel et. al., supra note 2, at 1; see also OfFICE OF GENERIC DrugS, CTR. FOR Drug EVALUATION \& RESEARCh, 2015 ANNUAL OGD ANNUAL REPORT: ENSURING SAFE, EFFECTIVE AND AFFORDABLE MEDICINES FOR THE AMERICAN PUBLIC 10, (2015), https://perma.cc/R7P9-4YYD. The FDA reports that the Office of Generic Drugs awarded 580 approvals and 146 tentative approvals in 2015. That year, there were 45 novel drugs approved. Thus, excluding the tentative generic approvals, $92.8 \%$ of drugs approved in 2015 were generics. Of the $7.2 \%$ of approved drugs that were novel drugs, approximately $47 \%$ of those were orphan drugs.

59. Known colloquially as the Hatch-Waxman Act for the legislators who crafted the law, the formal name is the Drug Price Competition and Patent Term Restoration Act, Pub. L. No. 98-417, 98 Stat. 1585 (1984) (hereinafter, "Hatch-Waxman Act"). For a detailed description of the Act, along with other sources discussing Hatch-Waxman, see Feldman \& Frondorf, supra note 40. See also, Elizabeth S. Weiswasser \& Scott D. Danzis, The Hatch-Waxman Act: History, Structure, and Legacy, 71 ANTITRUST L.J. 585, 585-90 (2003); FELDMAN, supra note 19, at 158; WENDY H. SCHACHT \& JOHN R. THOMAS, CONG. RESEARCh SERV., Report R41114, THE HATCH-WAXMAn ACT: A QUARTER CENTURY LATER (2011), http://congressional.proquest.com/congressional/result/congressional/pqpdocumentview :pdfevent?pgId=06b6d75e-812a-4075-accc-84ebb14f0182\&rsId=156CF64E551\&pdf=/app-bin/giscongresearch/f/a/7/8/crs-2011-rsi-0151_from_1_to_20.pdf; Matthew Avery, Continuing Abuse of the Hatch-Waxman Act by Pharmaceutical Patent Holders and the Failure of the 2003 Amendments, 60 HASTINGS L.J. 171 (2008); Gerald J. Mossinghoff, Overview of the Hatch-Waxman Act and Its Impact on the Drug Development Process, 54 Food \& DRUG L.J. 187 (1999); C. Scott Hemphill \& Mark A. Lemley, Earning Exclusivity: Generic Drug Incentives and the Hatch-Waxman Act, 77 ANTITRUST L.J. 947 (2011).

60. See 1 William C. Holmes, Intellectual Property and ANTitrust LaW $\S 1: 2$ (2007). 
compete with the branded drug company faced significant costs and delays, giving the branded drug companies time beyond the expiration of the patent to sail freely in the market. ${ }^{61}$ The problem arises through the interaction of the drug approval system with the patent system. Gaining FDA approval is a lengthy and complex process. Given that the patent system grants the right to exclude from making, as well as using and selling the drug, a would-be generic could not go through the steps to prepare for market entry without infringing the patent. ${ }^{62}$ Thus, competitors could never be ready to enter the market at the end of the patent term, and the branded company would enjoy continued market freedom.

A more serious problem revolves around the extensive cost of the clinical trials necessary to demonstrate the safety and efficacy of a medication. The original brandname company could recoup the costs of these trials through higher drug prices during the patent period. Once multiple generic drugs entered the market, however, the price would drop to the marginal cost of production. ${ }^{63}$ Thus, generic companies would have no incentive to enter into costly trials, given that there would be no opportunity to recoup those costs, and few generics would be willing to enter the market. ${ }^{64}$ Once again, this would leave the price of the drugs elevated beyond the expiration of the patent.

Hatch-Waxman aimed to resolve these problems by providing a pathway so that generic hopefuls would be prepared to enter the market quickly at the expiration of the patent. Among other provisions, the Act provided an abbreviated pathway so that companies applying for approval as a generic drug could rely on the safety and efficacy data created by the brand-name drug company. ${ }^{65}$ Under this Abbreviated New Drug Application ("ANDA"), the generic companies need only demonstrate that its drug is bioequivalent to the brand-name drug. ${ }^{66}$

The architects of Hatch-Waxman were concerned about an additional barrier to getting lower-priced drugs to consumers as quickly as possible: the existence of invalid patents. ${ }^{67}$ Thus, the Hatch-Waxman pathway included an incentive for generic hopefuls to challenge invalid patents and to engage in the necessary battles to overturn those patents. ${ }^{68}$ Specifically, Hatch-Waxman provides that the first generic to challenge a patent as invalid or not properly applying to the drug will be entitled to a six-month period in which no other generic company can enter the

61. See Schacht \& ThOmas, supra note 59, at Summary; Roche Prods., Inc. v. Bolar Pharm. Co., 733 F.2d 858, 863-64 (Fed. Cir. 1984) ("The [brand-name companies] gain for themselves, it is asserted, a de facto monopoly of upwards of 2 years by enjoining FDA-required testing of a generic drug until the patent on the drug's active ingredient expires.").

62. See FELDMAN, supra note 19, at 159.

63. See id. (citing studies showing that the price of a drug drops $20-30 \%$ when the first generic enters the market and may drop over $50 \%$ when additional generics enter)

64. See Kristin E. Behrendt, The Hatch-Waxman Act: Balancing Competing Interests or Survival of the Fittest?, 57 FOOD \& DRUG L.J. 247, 249 (2002).

65. 21 U.S.C. $\$ 355(\mathrm{j})(2012)$.

66. Id. $\S \S 355(\mathrm{j})(2)(\mathrm{A})(\mathrm{i})-(\mathrm{v})(2012)$.

67. See 149 CONG. REC. at 16104 (2003) (Senator Hatch noting that the intention behind the 180day marketing exclusivity was to encourage vigorous challenges of patents held by drug firms).

68. 21 U.S.C. $\$ 355(\mathrm{j})(2)(\mathrm{A})(\mathrm{vii})(\mathrm{IV})(2012)$. 
market. ${ }^{69}$ Thus, during the six months, only the original branded company and the first generic filer can sell in the market. This benefit is available as long as the generic challenger does not lose its patent challenge in court and does not forfeit its right to the benefit by failing to meet certain regulatory requirements. ${ }^{70}$

\section{a. Six-Month Marketing Right for Generics}

Through these pathways, Hatch-Waxman created the first pieces of Regulatory Intellectual Property. The six-month exclusivity is a marketing right that prevents competitors from entering the market during this period of time, much the same way that a patent prevents competitors from making, using, or selling the patented invention for twenty years. ${ }^{71}$ Despite its brevity, estimates suggest that the six-month generic benefit is enormously valuable. ${ }^{72}$

The Hatch-Waxman Act was a masterpiece of legislative compromise. As one can imagine, pharmaceutical companies were not anxious to help generic companies quickly climb the onramp of competition. ${ }^{73}$ Thus, the Act offered various balms to

69. Id. $\S 355(\mathrm{j})(5)(\mathrm{B})(\mathrm{iv})$. This is commonly known as filing a "Paragraph IV certification." See Feldman \& Frondorf, supra note 40, at 507-08

70. 21 U.S.C. $\S 355(j)(5)(D)(i)-(i i)$ (2012). Amendments to Hatch-Waxman in the 2003 Medicare Prescription Drug, Improvement, and Modernization Act set forth six instances in which the generic challenger may forfeit its 180-day exclusivity period, without losing a patent infringement case: (1) Failure to market the drug by the later of, one, the earlier of 75 days after the generic was approved or 30 months after the generic submitted its application, and two, 75 days after the challenged patents have been deemed invalid or not infringed, (2) Withdrawal of the application, (3) Amendment or withdrawal of certification for patents which qualified the applicant for the 180-day exclusivity period, (4) Failure to obtain tentative approval within 30 months of filing, (5) Determination by the Federal Trade Commission or a court that an agreement between the first applicant and another applicant, the holder of the listed drug, or a patent owner, has violated antitrust laws, (6) Expiration of all patents to which the applicant submitted a certification qualifying it for the 180-day exclusivity period. The FDA interprets these six forfeit provisions broadly.

71. See text accompanying notes 25-31 (comparing and contrasting patents and marketing rights).

72. See Matthew Avery, Continuing Abuse of the Hatch-Waxman Act by Pharmaceutical Patent Holders and the Failure of the 2003 Amendments, 60 HASTINGS L.J. 171, 178, nn.55-56 (2008) (citing Leila Abboud, Drug Makers Use New Tactic to Ding Generics, WALl ST. J. B1 (Jan. 27, 2004) ("In 2002, when Barr successfully challenged the patent protection on Eli Lilly \& Co.'s big antidepressant Prozac, Barr got revenue of about $\$ 368$ million from the new drug, or 31\% of its total for the year.”); Daniel F. Coughlin \& Rochelle A. Dede, Hatch-Waxman Game-Playing from a Generic Manufacturer Perspective, 25 BIOTECH L. REP. 525, 525-26 (2006) ("In general, most generic companies estimate that $60 \%$ to $80 \%$ of their potential profit for any one product is made during this exclusivity period.")).

73. See, e.g., Stephanie M. Greene, A Prescription for Change: How the Medicare Act Revises Hatch-Waxman to Speed Market Entry, 30 J. CORP. L. 309, 315 ("[T]he brand-name drug companies opposed provisions of the Hatch-Waxman Act that expedited generic entry, arguing that strengthening the generic drug industry would weaken incentive for innovation."); Drug Price Competition and Patent Term Restoration Act of 1984: Hearing Before the S. Comm. on Labor and Human Res., 98th Cong. 105-107 (1984) (hereinafter "Hatch-Waxman Hearing") (testimony of Verne Willamen, Member, Exec. Comm., Johnson \& Johnson, accompanied by John R. Stafford, Pres., Am. Home Prods., and Irwin Lerner, Pres./CEO, Hoffman-Laroche, Inc.) (expressing opposition to Hatch-Waxman on basis that accelerating approval process for generics will discourage innovative activity by pharmaceutical companies); HatchWaxman Hearing (statement of William E. Schuyler, Jr., former Comm. of Patents) (speaking on behalf of coalition of pharmaceutical companies, arguing that the bill is weighted too heavily in favor of generic companies); Innovation and Patent Law Reform: Hearings before the Subcomm. On Courts, Civil Liberties, and Admin. of Justice of the H. Judiciary Comm., 98th Cong. 423-426 (1984) (testimony of 
sooth the pain of generic competition. The first benefit does not create any new intellectual property and is indicated in the formal name of the Act-Drug Price Competition and Patent Term Restoration Act. ${ }^{74}$ Specifically, the Act provides that a patent's term may be extended for up to five years to compensate for certain defined delays at regulatory agencies. ${ }^{75}$

In addition, Hatch-Waxman's generic pathway created another form of Regulatory Property. Recall that generic hopefuls would now be able to use or reference in their applications the safety and efficacy data developed by the brandname drug company. Hatch-Waxman provided, however, that generic companies could not use this data for periods of time in the following two circumstances: data rights for new chemical entities and data rights for new clinical studies.

\section{b. Five-Year (or Four-Year) Data Right for New Chemical Entities}

Under Hatch-Waxman, generic hopefuls may not use clinical data from the branded drug company for five years, if the branded drug is designated as a new chemical entity. ${ }^{76}$ A new chemical entity is defined under the Act as "a drug that contains no active moiety that has been approved by the FDA."77

The five-year data right is shortened to a four-year data right if a generic hopeful files for FDA approval certifying its intent to challenge the patent on the drug as invalid, not enforceable, or not infringed. ${ }^{78}$ This data right ensures a period of time in which the brand-name drug company will be protected from competition, regardless of whether the patent is invalid. Even if the generic succeeds in overturning the patent before the end of the data rights, the data rights would still hold.

Rather than referencing the brand-name company's safety and efficacy data, a generic hopeful could choose to conduct its own clinical trials and submit the data to obtain FDA approval. As described above, however, the generic company most likely would be unable to recoup the cost of the clinical trial with higher prices, making this pathway unacceptable. ${ }^{79}$ The existence of the branded drug would be considered prior art under the patent system, eliminating the potential for patent

John R. Stafford, Pres., Am. Home Prods. et al.) (arguing that the legislation would encourage attacks on valid patents and allow generic companies to unconstitutionally take property from patent owners); Pharmaceutical Patent Issues: Interpreting Gait: Hearings before the S. Comm. on the Judiciary, 104th Cong. 102-105 (1996) (statement of John Klein, Chairman of the Generic Pharm. Indus. Ass'n).

74. See Hatch-Waxman Act, supra note 59.

75. See 35 U.S.C. $\S 156(\mathrm{~g})(6)(A)$. Although the patent can be extended by a maximum of five years, the maximum term remaining after approval cannot exceed fourteen years. See id. $\S 156(c)(3)$.

76. See 21 C.F.R. $\S 314.108(b)(2)$ (2016).

77. See 21 C.F.R. $§ 314.108(a)$; see also Dolin, supra note 51, at 1451. See Hoffmeister et. al., supra note 54 (discussing court and regulatory interpretations of the statute that provide new chemical entity status for (1) isolated components of a previously approved mixture or (2) a drug that is a combination of previously approved mixtures and at least one new active ingredient).

78. See 21 C.F.R. § 314.108(b)(3); see also Lal, supra note 47, at 3 (describing New Chemical Entity Exclusivity); see also supra note 69 and accompanying text (describing Paragraph IV certifications).

79. See supra text accompanying notes 59-60. 
protection. Similarly, the branded drug would constitute an active moiety approved by the FDA, eliminating the potential for five years of data protections for a new chemical entity. In short, newcomers rarely will have an incentive to enter the market under the current system, until the data rights have expired.

One should also note that the four or five-year data rights for new chemical entities are actually longer in practice. Given that one cannot use the branded company's data for a period of time, the FDA will not begin considering an application until the rights have expired. FDA approval would then take one to two years beyond that time, at least. Thus, the five-year data right, for example, is likely to keep competitors out of the market for seven years. ${ }^{80}$

Ironically, this is the type of delay that Hatch-Waxman tried to eliminate by creating ready-to-market pathways so that generics could enter as soon as the patents expire. Here, competition is still likely to be delayed, even when the data rights end.

As described above, this type of Regulatory Property looks much like trade secret protection, in that a competitor cannot use a company's clinical trial data but could develop the information on its own. ${ }^{81}$ The notion that regulatory data should be considered secret and proprietary to the company that created it is a relatively new legal concept. The concept emerged in the early 1980 s with the creation of data protection for pharmaceuticals, and the creation of data protection for pesticides in a different piece of legislation. ${ }^{82}$ Scholars have differed on the question of whether information necessary to gain approval from a public agency should ever be considered a proprietary secret. ${ }^{83}$ On the flip side, industry representatives have raised the question of whether an unconstitutional taking occurs if the FDA uses the data to approve a third party's drug without paying just compensation to the company that generated the drug. ${ }^{84}$

80. See Thomas, supra note 32, at 5 (explaining the delay and noting that the real world impact of the new chemical entity exclusivity is seven years).

81. See supra notes 32-37 and accompanying text.

82. See Federal Insecticide, Fungicide and Rodenticide Act (FIFRA), 7 U.S.C. § 136, et. seq; Reichman, supra note 12, at 12 n.45 (noting that concerns over preserving confidentiality of regulatory data have surfaced only in the last twenty-five years); see generally TREVOR M. COOK, SPECIAL REPORT: THE Protection of Regulatory Data in Pharmaceutical \& Other SECTORS (2000).

83. Compare Reichman, supra note 12, at 9 (arguing that there is a basic conceptual flaw in treating clinical trials as a private rather than a public good) with Lietzan, supra note 50, at 95 (2016) (arguing that data exclusivity should be understood not as a government grant but as a period of time when all competitors face the same barriers to entry).

84. See, e.g., Letter from Bruce N. Kuhlik, Senior Vice President and General Counsel, PhRMA, \& Caroline J. Loew, Vice President of Scientific and Regulatory Affairs, PhRMA, to FDA Division of Dockets Management (Nov. 12, 2004), available at http://www.fda.gov/ohrms/dockets/dockets/04p0171/04p-0171-c000006-vol1.pdf (arguing in support of Genentech's citizen petition asking that the FDA refrain from approving a biologic product that such approval, based on trade secret and confidential commercial information, would represent an unconstitutional taking); Letter from Kathleen M. Sanzo, Counsel for Pfizer Inc. and Pharmacia Corporation, to FDA Dockets Management Branch (July 27, 2001), available at http://www.fda.gov/ohrms/dockets/dockets/06p0450/06p-0450-cp00001-04-Appendix-A-03-vol1.pdf (asserting that use of an innovator's safety and effectiveness data to approve a $\$ 505(\mathrm{~b})(2)$ application constitutes an unconstitutional taking in violation of the Fifth Amendment); John C. Yoo, Takings Issues in the Approval of Generic Biologics, 60 FOOD DRUG COSM. L.Q. 33 (2005) (citing brand companies who claim that reliance on proprietary data in approving generic applications could constitute an 


\section{c. Three-year Data Right for New Clinical Studies}

Hatch-Waxman created an additional set of data rights aimed at new clinical studies - not to be confused with new chemical entities - that support new approvals of existing drugs. These data rights are available for improvements on existing drugs; for example, new dosages or new indications of an existing drug that is marketed and approved. ${ }^{85}$ They have also been granted for new studies related to switching from prescription to over-the-counter for an existing drug. ${ }^{86}$

Data rights for new clinical studies used to support changes to existing drugs last for three years. Unlike its sister regime for new chemical entities, the FDA can accept a generic application during the three years and begin considering the approval, but it cannot grant approval until the three-year period of the data rights has expired. $^{87}$

As is generally true with various Regulatory Property and other types of intellectual property rights, data rights for new clinical studies can be added to other data rights. Thus, for example, a company could receive a five-year data rights period for a new chemical entity. Later in the life of the drug, the company could engage in new clinical studies, obtain a pediatric approval, and extend those data rights for an additional six months. ${ }^{88}$

\section{d. The Hatch-Waxman Data Rights in General}

The remarkable complexity of these provisions is a testament to the legislative compromises embodied in the outcome. That complexity may also have affected the ability of scholars and commentators to visualize these rights as intellectual property rights. A twenty-year patent right is far easier to wrap one's head around than the complex, three-year or five-year (unless it is four-year) structure of the data rights in Hatch-Waxman.

It is certainly true that the data rights legislation packs an enormous amount of complexity into its provisions. Nevertheless, other forms of intellectual property are not the models of elegant simplicity one might imagine. The term of Copyright certainly is not sleek at "life of the author plus 70 years" unless it is a corporate author, in which case the term is "95 years from first publication or 120 years from creation, whichever comes first." 89 And, as described above, patents may be extended to reflect regulatory delays. No form of intellectual property can claim to be free of internal complexity, even as to term length. ${ }^{90}$

unconstitutional taking of private property).

85. See 21 C.F.R. $\$ 314.108(5)(\mathrm{ii})$; see also Thomas, supra note 32, at 6.

86. See Thomas, supra note 32 , at 6 .

87. See id. at 7.

88. See id.; Brook K. Baker, Ending Drug Registration Apartheid: Taming Data Exclusivity and Patent/Registration Linkage, 34 AM. J.L. \& MED. 303 (2008); see also Reichman, supra note 12, at 13.

89. $\quad$ See 17 U.S.C. $\S \S 302(\mathrm{a})$, (c).

90. One scholar suggests that Hatch-Waxman Regulatory Property can be distinguished from other forms of Regulatory Property in an important manner. The various rights Congress provided to pharmaceutical companies in Hatch-Waxman can be understood to some extent as "compensatory," in that they provide some recompense for the time that regulators "take" in the clinical trial process. In 


\section{Orphan Drugs}

Ah, the plight of orphans. Of all the brilliant strategic choices ever made, naming this regulatory scheme "The Orphan Drug Act" surely ranks among the most inspired. After all, who could oppose medical treatment for orphans-particularly not when Congressional testimony includes Hollywood stars re-enacting heartwrenching dramatizations?

The history of the Act and its legacy are more complex than the name might imply, however. The program was intended to provide incentives for the development of drugs to treat diseases that affect only small numbers of patients, on the theory that when the customer base is limited, the potential returns are too low to stimulate drug research and development. The program has spread like wildfire, however, to the point at which orphan drugs accounted for more than 40 percent of drugs approved by the FDA in 2015. ${ }^{11}$ As one scholar has noted, what do we do, "[w] hen everyone is an orphan?"92

Timing of the Orphan Drug Act differs slightly from that of the other types of Regulatory Property described above. The 97th Congress passed the original Orphan Drug Act, while the Hatch-Waxman Act did not pass until the 98th Congress. ${ }^{93}$ Thus, both Acts were under consideration during the same time, although they passed in separate Congresses. ${ }^{94}$

The timing of the two initiatives matches precisely, however, when one looks at the key amendment to the Orphan Drug Act. The original Orphan Drug Act was not a rousing success, and commentators have suggested that pharmaceutical companies were reluctant to submit applications under the definitions in the Act as passed. ${ }^{95}$ In response, the same Congress that passed the Hatch-Waxman Act also amended the key definition in the Orphan Drug Act, and the orphan drug program took off from there. ${ }^{96}$

contrast, provisions such as the Orphan Drug Act explicitly provide additional incentives. See Correspondence from Heidi Williams (Sept. 28, 2016) (on file with author).

91. See Daniel et. al., supra note 2, at 1; see also OFFICE OF GENERIC DRUGS, supra note 58.

92. The quoted phrase is the title of an article by Matthew Herder. See Matthew Herder, When Everyone Is an Orphan: Against Adopting a U.S.-Styled Orphan Drug Policy in Canada, 20 ACCOUNTABILITY IN RES. 227, 227 (2013).

93. See Orphan Drug Act, Pub. L. No. 97-414, 97 H.R. 5238, 97th Cong. (1983); Hatch-Waxman Act, supra note 59.

94. See Donald O. Beers \& Kurt R. Karst, Generic and Innovator Drugs: A Guide to FDA APPROVAl REQUiREMENTS app. 34-3 (8th ed. 2016) (noting that in the 97th Congress, the Senate unanimously passed a patent term restoration bill, but the House of Representatives narrowly failed to approve); Gerald J. Mossinghoff, Overview of the Hatch-Waxman Act and Its Impact on the Drug Development Process, 54 FoOD \& DRUG L.J. 187, 188 (describing the failure of Patent Term Restoration Act in the 97th Congress and its transformation into a patent term restoration and drug price competition bill in the 98th Congress); Albert Gore, Jr., Patent Term Extension: An Expensive and Unnecessary Giveaway, 1 HeAlth AfF. 25, 26 (1982) (discussing legislation introduced in the 97th Congress which would extend patent term for pharmaceuticals).

95. See Loughnot, supra note 56, at 375; see also Gary A. Pulsinelli, The Orphan Drug Act: What's Right With It, 15 SANTA ClaRA HigH TECH. L.J. 299, 307 (noting that the response to the 1983 Orphan Drug Act was "underwhelming").

96. See Health Promotion and Disease Prevention Amendments of 1984, Pub. L. No. 98-551, 98 Stat. 2815 (1984) (passed on Oct. 11, 1984, with amendment to orphan drug definition); Hatch-Waxman 
There have been other amendments to the Orphan Drug Act across time, however, but these have not had the same impact as the amendment passed at the same time as

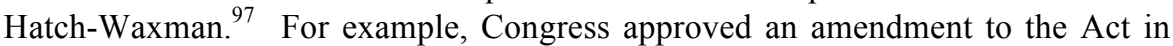
1985 to include patentable as well as unpatentable drugs in the program and in 1988 requiring sponsors to apply for orphan designation before applying for drug approval. A graph of designations and approvals of Orphan Drugs from the Department of Health and Human Services, however, shows no significant jump in approvals in the year following either amendment. ${ }^{98}$ In short, the key moment in the history of the Orphan Drug Act program took place in the same Congress as passage of the HatchWaxman Act, and the Act should be understood as part of the benefits granted to the branded pharmaceutical industry at this time.

\section{a. Logic and Structure of the Orphan Drug Act}

As described above, the Orphan Drug Act was intended to stimulate investment in the creation and production of drugs that treat diseases that affect only small numbers of people. Policy makers were concerned that such small populations would not make a revenue base sufficient to recoup the costs, and thus, these disease populations would languish untreated.

The original Orphan Drug Act defined a rare disease as one for which there was no "reasonable expectation that the cost of developing . . . will be recovered from sales in the United States." 99 The 1984 amendment, however, greatly expanded the definition of rare disease so that a drug now qualifies if it meets either of the following two definitions: (1) diseases affecting fewer than 200,000 people in the United States; or (2) diseases that affect more than 200,000 people in the United States but for which there is no reasonable expectation that sales would recover the costs. ${ }^{100}$ As noted in a government report, the 200,000 threshold was an arbitrary number that was chosen based on the estimated prevalence of narcolepsy and multiple sclerosis. ${ }^{101}$

A drug does not have to be new to qualify for orphan drug status. If existing drugs are approved for an orphan indication, those drugs will receive the benefits of the Act as well. ${ }^{102}$ For example, thalidomide, an anti-nausea drug that fell out of favor in the 1960s when it was linked to birth defects, received an orphan drug designation in 1998 for the treatment of leprosy and in 2006 for the treatment of a form of cancer called multiple myeloma. ${ }^{103}$

The practice of repurposing old drugs as new orphans has made the national news

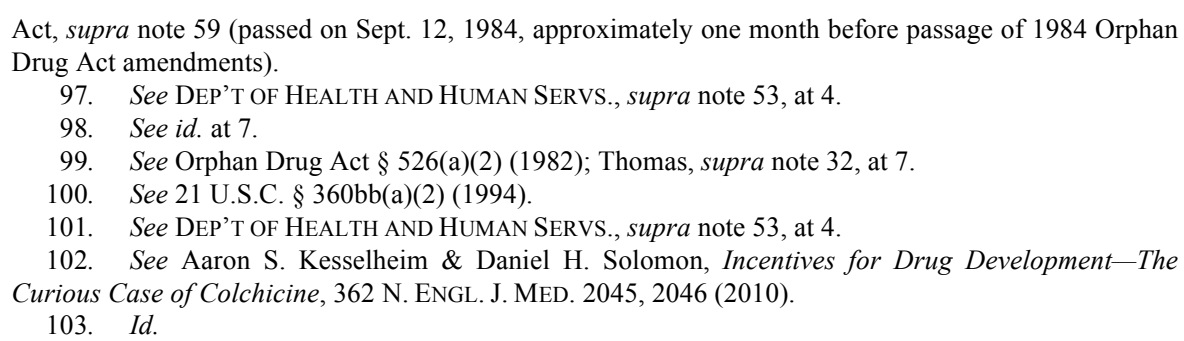


recently, and not in a flattering manner. For example, patients with a rare neuromuscular disease had been using the drug, 3,4-diaminopyridine ("3,4-DAP"), for over thirty years; anecdotal data had shown 3,4-DAP to be safe and effective since 1983. ${ }^{104}$ The drug had never received FDA approval but was provided to patients for free through a generous company and the FDA's "compassionate use" Investigational New Drug ("IND") program. ${ }^{105}$ In 2015, another company filed an application for orphan drug approval of a modified version of the drug that does not need refrigeration. ${ }^{106}$ The press report suggests that while the drug costs $\$ 600$ to make a year's supply for one patient, the company plans to sell it in the range of $\$ 100,000$ per patient each year. ${ }^{107}$

The Act provides a variety of benefits for pharmaceutical companies who develop medicines to treat rare diseases, including tax breaks, priority review by the FDA, and various grants. ${ }^{108}$ The greatest benefit, however, is seven years of marketing rights. Notwithstanding limited exceptions, these are the quasi-patent rights that will generally prevent the FDA from granting approval to any other company to make the same drug for the same orphan indication, regardless of whether the other company relies on its own clinical trial data. In other words, it is the granddaddy of the rights, both from the perspective of the power of the right and from the perspective of how long it lasts. Seven years is, by far, the longest of any of the forms of Regulatory Property. Thus, it is not surprising that the program has attracted considerable interest from pharmaceutical companies.

Wonderful drugs have been approved through the Orphan Drug Act portal. ${ }^{109}$ These have included treatments for a rare genetic disorder called Gaucher's disease, a truly rare form of the already rare Ebola virus, and many others. ${ }^{110}$ Some would

104. See Ted M. Burns et al., Editorial by Concerned Physicians: Unintended Effect of the Orphan Drug Act on the Potential Cost of 3,4-Diaminopyridine, 53 MuSCLE NERVE 165, 166-67 (2016).

105. Id. The "compassionate use" IND program gives patients with serious or life-threatening diseases access to drugs that are still undergoing clinical trials, if there are no comparable or satisfactory therapeutic alternatives available. See Alexander Gaffney, Regulatory Explainer: FDA's Expanded Access (Compassionate Use) Program, Reg. AfF. Prof. Soc'Y (Feb. 4, 2015), available at http://www.raps.org/Regulatory-Focus/News/2015/02/04/18343/Regulatory-Explainer-FDAs-ExpandedAccess-Compassionate-Use-Program/.

106. See Sabrina Tavernise, Patients Fear Spike in Price of Old Drugs, N.Y. TimEs (Dec. 22, 2015), available at $\mathrm{http} / / / \mathrm{www}$.nytimes.com/2015/12/23/health/patients-fear-spike-in-price-of-old-drugs.html.

107. Id.

108. See Orphan Drug Act, Pub. L. 97-414, 96 Stat. 2049 (1982); Thomas, supra note 32, at 8. Orphan drug companies are eligible for up to $\$ 500,000$ a year for up to four years, a tax credit of $50 \%$ of qualifying clinical trial costs, a waiver of application fees worth more than $\$ 2$ million, and what I would call "concierge service at the FDA," that is, assistance from the FDA on what tests and trials the drug company needs to complete to secure marketing approval. See Daniel et. al., supra note 2, at 210; Pulsinelli, supra note 95, at 6 . For example, in the drug approval process ordinarily, the FDA maintains a distant, objective, and some would say antagonistic, relationship with the applicant, while during orphan drug approval process, the FDA establishes a more collegial relationship, working with the company to get the trials accomplished and move the drug to market expeditiously. See Loughnot, supra note 56, at 368 .

109. See Thomas Maeder, The Orphan Drug Backlash, 288 SCI. AM. 80, 87 (2003) (quoting Abbey S. Meyers, President of the National Organization for Rare Disorders, as saying "[t]he Orphan Drug Act works fabulously well. ... We have treatments we never imagined we would").

110. See Daniel et. al., supra note 2, at 210. 
say, however, that the program has been too successful. In fact, orphan drugs seem to be dominating the modern medical system. For example, in 2015, more than 40 percent of all FDA-approved drugs on the market were submitted as orphan drugs, ${ }^{111}$ and over 41 percent of the new drugs approved by the FDA in 2014 were for drugs that had an orphan indication. ${ }^{112}$ Moreover, of the drugs forecast to be the top ten best-selling drugs in 2015, seven were drugs with some form of orphan indication. ${ }^{113}$

The same is true for drugs that are regulated by the FDA as biologics. ${ }^{114}$ In 2001 , five of the ten best-selling biologic drugs were originally approved as orphan drugs and three more were approved for orphan indications in addition to their original use. $^{115}$ In other words, 80 percent of the best-selling biologics were related to the Orphan Drug Act in some manner-and that was only in 2001.

It is not surprising that so many of the best-selling biologic drugs have orphan designations. Modern biologics tend to be targeted at specific patient populations, making the area ripe for universal orphan designation. In fact, some scholars have bemoaned the fact that the Orphan Drug Act is driving medical science overwhelmingly towards cancer therapeutics. ${ }^{116}$ Cancer therapeutics focus on precision medicine techniques and small, particularized populations that are defined by DNA diagnostic testing, for which orphan drug designations are a natural fit. As one commentator noted, "all cancers but four are considered to be rare diseases." "117 Although cancer is certainly an important health concern, one could question whether so much of societal energy should be directed at cancer, and whether Congress intended this result.

The dominance of orphan drugs also can be seen in the value of total sales. For example, one group projects that between 2014 and 2020, orphan drug sales will increase at twice the rate of overall prescription drug sales worldwide, with orphan drug sales reaching $\$ 176$ billion in 2020. ${ }^{118}$ Following those projections, orphan drug sales will constitute almost 20 percent of worldwide prescription drug sales as a whole by 2020 .

Finally, the price of orphan drugs is shockingly high. The median cost per patient to use an orphan drug for one year is almost $\$ 99,000 .{ }^{119}$ In comparison, for non-

\footnotetext{
111. See sources cited at note 54, supra.

112. See CTR. FOR Drug EVALUATION AND RESEARCH, U.S. FoOd AND DRUG AdMIN., NOVEL NEW DRUGS $2014 \quad$ SUMMARY $\quad 5 \quad$ (Jan. http://www.fda.gov/downloads/Drugs/DevelopmentApprovalProcess/DrugInnovation/UCM430299.pdf, (explaining that over $41 \%$ of the novel drugs approved in $2014-17$ of $41-$ were approved to treat orphan diseases).

113. See Daniel et. al, supra note 2, at 211.

114. For an explanation of the difference between chemical (also known as small molecule) drugs and biologic drugs, see text accompanying notes 134-144 infra.

115. See Maeder, supra note 109 , at 84.

116. See Herder, supra note 92, at 247-49; see also Olivier Wellman-Labadie \& Youwen Zhou, The US Orphan Drug Act: Rare Disease Research Stimulator or Commercial Opportunity?, 95 HEALTH POL'y 216, 225 (2010) (discussing the trend and its implications).

117. See Wellman-Labadie \& Zhou, supra note 116, at 225 (citing Abbey S. Meyers, Executive Director of the National Organization for Rare Disorders).

118. Andreas Hadjivasilou, EvAlUATEPHARMA, ORPHAN DRUG REPORT 2014, at 4 (Oct. 2014), available at http://info.evaluategroup.com/rs/evaluatepharmaltd/images/2014OD.pdf.

119. Daniel et. al., supra note 2, at 2 (citing Hadjivasilou, supra note 118, at 8).
} 
orphan drugs, the cost is roughly $\$ 5,000 .{ }^{120}$ In addition, the price tag for the most expensive orphan drugs soars well above the median. The poster child is Genzyme's drug Cerezyme, which is an enzyme replacement therapy for treating the genetic disorder known as Gaucher's disease. The company reportedly charged between $\$ 100,000$ and $\$ 400,000$ a year per patient, depending on whether the patient was a child or an adult, earning close to half a billion dollars a year. ${ }^{121}$

To some extent, high prices for orphan drugs may be perfectly understandable. If a company must recoup its investment over a small group of customers, the cost per customer is bound to be high. After all, one could argue that an expensive treatment is better than no treatment at all. The problem is that in many cases, those high prices seem to be spread across much larger populations than the Act anticipates. In other words, critics note that companies earn the right to charge mega-prices by claiming to serve small populations, and then use various techniques to charge those megaprices across broader populations. ${ }^{122}$ One could call these techniques "spillover pricing."

Spillover pricing can occur in a variety of ways. The simplest is through off-label use. Off-label use occurs when doctors prescribe a medicine to treat something that is not one of the indications approved by the FDA. ${ }^{123}$ It is a common practice in medicine. In fact, the Second Circuit recently ruled that given the First Amendment

120. Id.

121. See Maeder, supra note 109, at 85-86. Genzyme was acquired by the French pharmaceutical company Sanofi in 2011. See Jeanne Whalen \& Mimosa Spencer, Sanofi Wins Long-Sought Biotech Deal,
WALL ST.
$\mathrm{J}$.
(Feb.
17 , 2011) http://www.wsj.com/articles/SB10001424052748703373404576147483489656732. In 2014, worldwide sales of Cerezyme reached nearly one billion dollars. See Evaluate, Cerezyme (2016), https://www.evaluategroup.com/View/15461--1002-modData/product/cerezyme; Carolyn Y. Johnson, High Prices Make Once-Neglected Drugs a Booming Business, WASH. Post, (Aug. 4, 2016), https://www.washingtonpost.com/business/economy/high-prices-make-once-neglected-orphan-drugs-abooming-business/2016/08/04/539d0968-1e10-11e6-9c81-4be1c14fb8c8_story.html.

122. See, e.g., Daniel et al., supra note 2; Maeder, supra note 109, at 85; Brian B. Eller, Promoting Innovation in the Pharmaceutical Industry by Expanding the FDA's Regulatory Powers to Grant Market Exclusivity, (Dec. 19, 2010) (unpublished manuscript) (http://papers.ssrn.com/sol3/papers.cfm?abstract_id=1790566), text accompanying note 106; Loughnot, supra note 56, at 366; Herder, supra note 92, at 247; Pulsinelli, supra note 95, at 315-16. For similar observations related to orphan drug pricing in other countries, see Panos Kanavos \& Elana Nicod, What is Wrong With Orphan Drug Policies: Suggestions for Ways Forward, 15 VAlue IN Health 1182, text accompanying note 19 (2012); Alain Denis, et al., Issues Surrounding Orphan Disease and Orphan Drug Policies in Europe, 8 ApP. Health Econ. Health Pol. 343 (2010); Eline Picavet, Thomas Morel, David Cassiman \& Steven Simoens, Shining a Light in the Black Box of Orphan Drug Pricing, 9 ORPHANET J. OF RARE DISEASES 62 (2014).

123. Most commonly, "off-label use" refers to the prescription of a currently available medication for an indication (disease or symptom) that has not received FDA approval. It can, however, also refer to the use of a medication in a patient population, dosage, or dosage form that has not received FDA approval. See Christopher M. Wittich et al., Ten Common Questions (and Their Answers) About Off-label Drug Use, 87 MAYO CLIN. PROC. 982, 982 (2012). The practice of off-label use is common, with rates of up to $40 \%$ in adults and up to $90 \%$ in some hospitalized pediatric populations. See Madlen Gazarian et al., Off-Label Use of Medicines: Consensus Recommendations for Evaluating Appropriateness, 185 MED. J. AUST. 544 , 544 (2006). Off-label prescriptions are legal, and can allow for life-saving innovation in clinical practice. See Randall S. Stafford, Regulating Off-Label Drug Use-Rethinking the Role of the FDA, 358 N. ENGL. J. MED. 1427, 1427 (2008). 
protections for freedom of speech, the FDA cannot prevent a drug company from promoting a drug for off-label uses, as long as the message is truthful and not misleading. ${ }^{124}$

Off-label uses can be a great boon for orphan drug makers. A company can seek approval from the FDA to use their drug for treatment of a small population-small enough to fit within the Orphan Drug Act's definition of fewer than 200,000 people in the United States. After approval, the company may be able to expand the patient population well beyond the 200,000 through additional off-label uses. ${ }^{125}$

For example, the Lidoderm patch was originally approved for a painful complication of shingles that affects nerve fibers. ${ }^{126}$ One study found, however, that the company earned more than $80 \%$ of its revenue from uses other than the original orphan drug indication, when examining Medicare spending in two states. ${ }^{127}$

Perhaps the classic case of off-label expansion of an orphan drug can be seen with Epogen. The FDA originally approved Epogen with an orphan designation for the treatment of anemia related to end-stage renal disease. ${ }^{128}$ After approval, the drug became widely prescribed for treating a variety of forms of anemia - some approved uses and some off-label, generating billions of dollars of revenue for the company. ${ }^{129}$

At first glance, one might wonder why in the world this strategy would work. After all, under the Orphan Drug Act, the FDA grants seven years of marketing exclusivity, but only for the particular orphan indication. ${ }^{130}$ In other words, if there is no orphan drug exclusivity for those off-label uses, why wouldn't another company jump in to compete for the off-label use?

In order to get off-label use of one's drug however, one has to get onto the market in the first place. A competitor could not get onto the market for the same orphan indication, which is blocked by seven years of orphan exclusivity. The competitor could try to get approval for the drug directly for the off-label use, but that would require much time and extensive clinical trials. Those clinical trials, of course, would not have the many advantages of orphan drug clinical trials, including priority review at the FDA, financial grants, and tax breaks. Thus, in reality, one can obtain the benefits of orphan drug status while garnering spillover returns from a much larger

124. See United States v. Caronia, 703 F.3d 149 (2d Cir. 2012).

125. Though a physician can prescribe an orphan drug for off-label uses, orphan drug status does not preclude approval of the same drug for another disease or condition. See Rebecca S. Eisenberg, The Problem of New Uses, 5 Yale J. Health Pol'y L. \& Ethics 717, 726-27 (2013) (citing Sigma-Tau Pharm v. Schwetz, 288 F.3d 141 (4th Cir. 2002)).

126. See Daniel et al., supra note 2, at 212 (describing Lidoderm's initial approval for hypersensitivity in postherpetic neuralgia). For an explanation of postherpetic neuralgia, see Mayo Clinic Staff, Postherpetic Neuralgia, MAYO CLINIC (Sept. 16, 2015), available at http://www.mayoclinic.org/diseases-conditions/postherpetic-neuralgia/basics/definition/con-20023743.

127. See Daniel et al., supra note 2, at 3 (citing Aaron S. Kesselheim, et al., The Prevalence and Cost of Unapproved Uses of Top-Selling Orphan Drugs, PLOS ONE (Feb. 21, 2012), available at http://journals.plos.org/plosone/article?id=10.1371/journal.pone.0031894.

128. See Shannon Gibson \& Barbara von Tigerstrom, Orphan Drug Incentives in the Pharmacogenomic Context: Policy Responses to the US and Canada, 2 J.L. \& BIOsCIENCES 5 (2015), text accompanying notes 37-38, available at http://jlb.oxfordjournals.org/content/early/2015/05/18/jlb.lsv013.full.

129. See id.

130. See Lal, supra note 47, at 2 . 
off-label population.

In addition to off-label uses, companies can garner spillover returns by applying for separate orphan designations for different uses of the same drug. Once again, this presses against the original purpose of the Orphan Drug Act. For example, the FDA originally approved the drug Imatinib with an orphan designation for treating a rare form of leukemia that affects only 9,000 patients. ${ }^{131}$ The company subsequently received six additional orphan designations for treating other forms of cancer, a syndrome related to an autoimmune disease, and certain bone marrow disorders. ${ }^{132}$

If a single drug can be used for multiple patient populations, those populations added together should provide enough of a return to tempt the company to make the drug. The return certainly is reduced by the need to engage in separate clinical trials for different uses. Nevertheless, the costs of production and development of a stable, usable compound are spread across a much larger population than what Congress contemplated with its "orphan" designation.

A more extreme form of finding additional designations for a single orphan drug is known as "salami slicing." 133 With salami slicing, a company divides the treatment population into small slices and obtains different orphan designations for each slice. Divisions have been based, for example, on whether a particular disease is early stage or end stage, different manifestations of a disease, or different mutations leading to the same genetic disease. The risk is that companies could divide populations into ever-finer slices until, in theory, reaching the absurd point of testing headaches in males who just bumped their head on the car door in the last two weeks.

In 2013, the FDA issued guidelines intended to reduce salami slicing behaviors. ${ }^{134}$ The new guidelines are enormously complex, however, and the jury is still out on whether the guidelines will be successful. ${ }^{135}$

The policy implications of behaviors such as off-label uses, additional orphan designations, and salami slicing are unclear. On the one hand, one could argue that society should encourage drug makers to look for all possible uses for the medicines we already have. Society should exploit to the fullest those substances for which we have the greatest experience and knowledge, before we go chasing after new rainbows. On the other hand, a policy that encourages constant repurposing of what researchers already know risks ossifying scientific advancement.

Putting aside the policy implications, however, the economic implications are quite troubling. Congress passed the Orphan Drug Act for the purpose of creating incentives when patient populations were too small for drug companies to serve

131. See Daniel et al., supra note 2, at 212.

132. See id.

133. See Gibson \& von Tigerstrom, supra note 128. Some scholars use the term "salami slicing" to refer not only to additional approved uses but also to off-label uses of the same drug. See id., text accompanying notes 36-38 (describing the off-label uses of Epogen as a form of salami slicing).

134. See Orphan Drug Regulations (Final Rule), 78 Fed. Reg. 35117, 35120-21 (June 12, 2013) (to be codified at 21 C.F.R. pt. 316) (clarifying and providing guidance on the circumstances under which a subset of a common disease would qualify for an orphan designation).

135. See Gibson \& von Tigerstrom, supra note 128, and text accompanying notes 46-86 (describing the new guidelines and discussing uncertainty about the impact they will have); Daniel et al., supra note 2 at 212 (noting that the success of the 2013 wording change remains to be determined). 
them. When drug companies aggregate multiple populations, it defeats the purpose of the Act.

The saga of the Orphan Drug Act is tantalizingly reminiscent of the Gilbert \& Sullivan operetta, Pirates of Penzance. The pirates in the play have declared that they will never harm an orphan, and express frustration that "[e]veryone we capture says he's an orphan. The last three ships we took proved to be manned entirely by orphans, and so, we had to let them go.",136

What should society do as more and more companies show up at the FDA, claiming to serve orphans? At least with Gilbert \& Sullivan, the characters are unable to make any money from orphans. Here, however, it is the reverse. When so many companies claim they are only serving orphans, the orphans - that is, the patientsmay be the ones having their finances ravaged.

The Orphan Drug Act is the last of the pieces of Regulatory Property created at the time of passage of the Hatch-Waxman system in exchange for expedited approval of generic drugs. As described above, these forms of Regulatory Property include ones for first generic filers, new chemical entities, new clinical studies, and orphan drugs.

\section{B. Regulatory Property with the Affordable Care ACt}

The next major group of Regulatory Property benefits were granted during the Congress that passed the health care legislation known as the Affordable Care Act. As part of the Affordable Care Act, the 111th Congress also approved major legislation to create a pathway for accelerated approval of biologic drugs, known as the Biologics Price Competition and Innovation Act ("Biologics Act"). ${ }^{137}$ Unsurprisingly, the biotechnology and pharmaceutical industries both vigorously opposed the Biologics Act. ${ }^{138}$

136. W.S. Gilbert \& Arthur Sullivan, The Pirates of Penzance; or, The Slave of Duty: COMIC OPERA IN TWO ACTS 6 (1880).

137. For an explanation of biologic drugs, see supra text accompanying notes 134-144.

138. See Robert Weissman et Al., Public Citizen, Competition Inhibitors: How Biologics Makers are LeVeraging Political POWer to Maintain Monopolies AND KeEP Prices SKY-High 6 (2014), https://perma.cc/YXK2-KA76. Initially, industry associations such as BIO (Biotechnology Industry Organization) and PhRMA (Pharmaceutical Researchers and Manufacturers of America) argued that there should be no biosimilars pathway at all, claiming that it was impossible to make safe and effective copies of biologics. See Krista Hessler Carver et al., An Unofficial Legislative History of the Biologics Price Competition and Innovation Act of 2009, 65 FOOD \& DRUG L.J. 671, 708 (2010). Manufacturers such as Amgen and Genentech argued that biosimilars could not be shown to be "therapeutically equivalent" to the reference products, and that if biosimilars were to be approved, it would require a "full complement of critical animal and clinical studies." Letter from Kenneth Seamon, Amgen, Inc. to FDA, Docket No. FDA-2004-N-0059, 9-10 (2004). When it was clear that some sort of biologics pathway would be incorporated into the Affordable Care Act ("ACA"), the industry lobbied to make sure the pathway would be as restrictive as possible. Representative Anna Eshoo introduced a bill that set forth very stringent requirements for generic biologics, and her bill was incorporated into the enacted ACA. Rep. Eshoo has received more campaign contributions from the pharmaceutical industry than any other industry over the course of her career. See WeISSMAn ET AL., supra at 13 (citing Rep. Anna Eshoo: Industry Data, OpenSecrets.org: Center for Responsive Politics), https://perma.cc/ZQN8-R2YU. The pharmaceutical industry has also taken the biologics fight to the state level, proposing legislation to limit the ability of pharmacists to substitute generic biologics for their brand name products. See Andrew 
It is interesting to note that during roughly this same period in history, Congress was debating another major reform act with provisions opposed by the pharmaceutical industry. In the year following approval of the Biologics Act, Congress passed the patent reform act known as the America Invents Act. Approved in 2011, the America Invents Act included numerous changes to patent law, including creating a series of methods for third parties to challenge the validity of a patent at the Patent and Trademark Office after the patent has been granted. The pharmaceutical industry was deeply opposed to patent reform in general, and certain earlier iterations of the legislative proposal. The industry reluctantly supported the 2011 America Invents Act, however, because it was gutted of some of the most objectionable provisions, and because they were concerned that future iterations would be even less favorable to their interests. ${ }^{139}$ Although the patent reform act did not pass until the 112th Congress, that legislation was discussed and debated during the prior Congress as well, which passed the fateful Affordable Care Act with its biosimilar provisions. Given the historic proximity, this Article groups together the pieces of legislation passed in the 111th Congress and the 112th Congress as a single wave. And to make the pattern even more consistent, the 112th Congress approved legislation to tighten limits on the ability of pharmaceutical companies to obstruct generic entry using the FDA Citizen Petition process. ${ }^{140}$

Once again, in the period in which Congress passed legislation that the pharmaceutical industry bitterly opposed, Congress passed legislation that created forms of Regulatory Property. Thus, Congress created Regulatory Property for drugs for infectious diseases, biologics, and clinical trials for pediatric use of drugs. In

Pollack, Biotech Firms, Billions at Risk, Lobby States to Limit Generics, N.Y. TiMES (Jan. 28, 2013) at A1, available at http:/www.nytimes.com/2013/01/29/business/battle-in-states-on-generic-copies-ofbiotech-drugs.html.

139. Specifically, the pharmaceutical industry opposed a series of patent reform bills proposed between 2005 and 2011, including the 2009 Patent Reform Act. In 2011, however, Senator Patrick Leahy introduced an amended version that removed the provisions that the pharmaceutical companies found most objectionable. See Susanne Hollinger, The America Invents Act Implementation, 23 EXPERT Opinion Therapeutic PATENTs 545 (2013); PhRMA Statement on Patent Reform Act of 2009, PHRMA (Mar. 3, 2009), https://perma.cc/ZA4V-E4DF (expressing concern over more lenient penalties for patent infringers in the Act). Upon introduction of the Senate bill for the America Invents Act, it was widely believed that any further iteration of the bill would be even less favorable to the pharmaceutical industry; so many companies who were previously opposed to patent reform chose to support it. See Manus Cooney, The America Invents Act - How It All Went Down, IP WATChDog (Sept. 20, 2011), http://www.ipwatchdog.com/2011/09/20/the-america-invents-act-how-it-all-went-down/id=19294/;

PhRMA Statement on Patent Reform - 2011, PHRMA (June 23, 2011), https://perma.cc/Z2LL-G2AZ. Yet, the pharmaceutical industry began to take issue with implementation of the American Invents Act after its passage, lobbying for review exemptions for certain biopharmaceutical patents. See Matthew Bultman, Pharma Lobby Wants Some Patents Exempt from AIA Review, LAw360 (July 16, 2015), https://perma.cc/SA5M-DWPD.

140. As described below in the context of tropical disease vouchers, Congress attempted to reign in citizen petition abuse in 2007. See infra text accompanying note 197. The 2012 legislation tightened the 2007 restrictions by shortening the period of time for the FDA to respond to such petition efforts. See 21 U.S.C. §355(q)(1)(A); see also Robin C. Feldman, Evan Frondorf \& Andrew K. Cordova, Empirical Evidence of Drug Pricing Games-A Citizen's Pathway Gone Astray, (forthcoming) (discussing the legislation and presenting an empirical analysis of its failure to stop the targeted behavior), available at http://papers.ssrn.com/sol3/papers.cfm?abstract_id=2833151. 
general, the pattern among this wave of Regulatory Property can best be described as "just add more."

\section{Biologics}

The 111th Congress embarked on a process reminiscent of the Hatch-Waxman legislation for expedited approval of generic drugs. The Hatch-Waxman pathway only covers what is known as chemical drugs. The decades since introduction of the Hatch-Waxman system have witnessed the increased development of a relatively new breed of medicines knows as biologics. Biologics differ from ordinary chemical drugs both in terms of structure and in terms of the process of production. ${ }^{141}$

Consider first ordinary chemical drugs, such as aspirin. These are sometimes called small molecule drugs because their chemical structure is composed of relatively fewer atoms than biologics. ${ }^{142}$ A typical chemical drug is made up of dozens of atoms forming one molecule. ${ }^{143}$ The structure of a chemical drug is also relatively simple to understand and depict; one can typically draw the structure with a simple two-dimensional sketch. Finally, chemical drugs are far easier to make than biologics. $^{144}$ The proper chemical ingredients are combined in the lab and react together to form a new chemical. Although manufacturing any product is never quite so simple, the process of producing a chemical drug pales in comparison to the process for its cousin, the biologic.

Biologics differ greatly from their country cousins, chemical drugs. Rather than a few dozen atoms aggregating into one molecule, biologics contain thousands to millions of atoms formed into an intricately integrated set of perhaps thousands of molecules. ${ }^{145}$ These numerous molecules are folded into complex shapes that cannot be depicted in a simple two-dimensional drawing. ${ }^{146}$ Most importantly, biologics are so large and complex that scientists do not know how to build them chemically in an efficient manner. ${ }^{147}$ Instead, scientists use living cells, carefully nurtured in a laboratory setting to act as a form of living machinery to create the necessary substance. ${ }^{148}$ Given that biologic drugs are created through a process involving living cells, that process cannot be controlled with the same precision as mixing chemicals. ${ }^{149}$ Just as no two human beings could ever be precisely alike, it is virtually

141. See Wendy H. Schacht \& John R. Thomas, Follow-On Biologics: The Law and Intellectual Property Issues, CONG. Res. SERV. (2010) [hereinafter CONG. RES. SERV.: BIOLOGICS] (citing Gary C. Messplay \& Collen Heisey, Follow-On Biologics: The Evolving Regulatory Landscape, BIOEXECUTIVE INT'L 43 (2006)).

142. See Robert N. Sahr, The Biologics Price Competition and Innovation Act: Innovation Must Come Before Price Competition, B.C. InTELl. PROP. \& TECH. F. 1 (2009).

143. Bryan A. Liang, Regulating Follow-On Biologics, 44 HARV. J. ON LEGIS. 363, 369 (2007).

144. See Schacht \& Thomas, supra note 141, at 7.

145. See Liang, supra note 143, at 369.

146. See Sahr, supra note 142, at 2.

147. See id.

148. See id. (citing Benjamin Leader et al., Protein Therapeutics: A Summary and Pharmacological Classification, 7 NATURE REVS. DRUG DISCOVERY 21 (2008)).

149. See id. (citing Biotech. InNOvation Org., How Do Drugs and Biologics Differ?, https://perma.cc/QQ4H-2XXL). 
impossible to make a truly identical copy of, for example, a protein made using different production cell lines. ${ }^{150}$ Particularly concerning are subtle, virtually undetectable variations in structure or stability of the cell line that may result in a drug that is less effective or downright dangerous. ${ }^{151}$ Given the complexities of the drugs, the potential subtle differences, and the potential risks, the process for approval of copies of biologic drugs cannot be as streamlined as the process for approving generic versions of chemical drugs.

Prompted by the high cost of biologic drugs, the 111th Congress created a pathway for approval of copies of brand name biologics. ${ }^{152}$ The legislation was called the Biologics Act and was passed as a last minute addition to massive health care reform law known as the Affordable Care Act. ${ }^{153}$ The pathway for approval is far more rigorous than what is required for approval of generic drugs, and it involves more extensive testing and trials. Copies of biologic drugs are called biosimilars or interchangeables, rather than generics. " Receiving a designation of "biosimilarity" requires that the biological product is "highly similar" to the reference product and "no clinically meaningful differences between the biological product and the reference product in terms of the safety, purity, and potency of the product." 155 The designation of "interchangeable," meanwhile, is much less easily attainable, requiring that the biological product not only be biosimilar, but also be able to "produce the same clinical result as the reference product in any given patient" and exhibit no difference in risk or efficacy than the reference product. ${ }^{156}$ To date, only a couple of biosimilar products have been approved by the FDA, and no products have been approved as "interchangeable."

As with the Hatch-Waxman Act, the Biologics Act creates several forms of Regulatory Property for biologic drugs, but the Regulatory Property in the Biologics Act lasts longer than the Regulatory Property created in Hatch-Waxman. The following paragraphs describe the two acts in comparison, to highlight the differences.

As described above, the Hatch-Waxman Act created six months of marketing rights for the first generic filer who challenged a patent protecting the branded drug and three to five years of data rights for original pharmaceutical makers. ${ }^{157}$ In contrast to the Hatch-Waxman's six months of marketing rights, the Biologics Act contains no marketing rights for the first biosimilar filer, significantly reducing the allure of creating a biosimilar. For those who create interchangeables, however, the

150. See Liang, supra note 143, at 370 (citing Simon D. Roger, Biosimilars: How Similar or Dissimilar Are They?, 11 NePHROLOGY 341 (2006)).

151. See Sahr, supra note 142, at 3.

152. See 42 U.S.C.A. $§ 262$ (2015); see also Kate S. Gaudry, Exclusivity Strategies and Opportunities in view of the Biologics Price Competition and Innovation Act, 66 FoOD \& DRUG L.J. 587, 587-88 (2011).

153. Biologics Price Competition and Innovation Act of 2009, Pub. L. No. 111-148, 124 Stat. 804, 807 (2009) [hereinafter "Biologics Act"]. See Thomas, supra note 32, at 8-9.

154. See Ryan Timmis, The Biologics Price Competition and Innovation Act: Potential Problems in the Biologic-Drug Regulatory Scheme, 13 Nw. J. TeCH. \& INTELL. Prop. 215, 222 (2015).

155. See 42 U.S.C.A. § 262(i)(3).

156. See id. at $\S 262(\mathrm{k})(4)$.

157. See supra, text accompanying notes 66-82. 
period of marketing rights last much longer. ${ }^{158}$ There is a complicated calculus under the Biologics Act, depending on the state of any litigation, but the shortest period of time is twelve months. ${ }^{159}$

The Regulatory Property for the original drug maker is considerably longer and stronger under the Biologics Act. Specifically, the original drug maker receives twelve years of data rights under the Biologics Act. ${ }^{160}$ For the first four years, ${ }^{161}$ no follow-on companies may apply, even if they use their own data and if patents on the original drug are invalidated. For the remaining eight years, a follow-on company could apply and receive approval, but could not rely on any data from the original drug maker.

The language of the Biologics Act itself is less than a model of clarity, and arguably it could be read to suggest that original biologic drug makers receive twelve years of marketing rights, rather than twelve years of data rights. As described above, marketing rights are the stronger ones because they prevent the FDA from approving follow-on biologics created by any other companies, even those who use their own, original data. ${ }^{162}$ Following letters from members of Congress, however, the FDA has interpreted the twelve years in the Biologics Act to refer to only data rights. ${ }^{163}$

In short, the Biologics Act provides a less streamlined pathway for approval of follow on biologic drugs, and the Regulatory Property is generally longer and stronger. Commentators are skeptical of whether the Biologics Act will result in the same type of price reductions that consumers have enjoyed with generic drugs under the Hatch-Waxman regime. ${ }^{164}$ In addition to the more complex regulatory pathway, drug companies that make the original biologic drugs have been raising their prices in the years immediately prior to introduction of the biosimilar products, and the follow-on companies are setting their prices accordingly. ${ }^{165}$ The system is too new, however, and too few follow-on biologics have been approved for scholars to draw generalizable conclusions.

158. See 42 U.S.C.A. $§ 262(k)(6)$.

159. See Biologics Act, supra note 153. The precise time is the earlier of one year after commercial marketing, eighteen months after approval if not subject to litigation, eighteen months after final court decision or dismissal, or forty-two months after approval if litigation is ongoing. The varying times may reflect an attempt to head off the so-called pay-for-delay settlements under Hatch-Waxman. HatchWaxman has been plagued by deals in which the branded pharmaceutical company enters into a settlement with the would-be generic in which the generic agrees to stay off the market for a period of time in exchange for some form of payment. For a description of this behavior, along with discussion of the judicial, regulatory, and legislative responses, see Feldman \& Frondorf, supra note 40.

160. See 42 U.S.C.A. $\$ 262(k)(7)(A)$.

161. See id. $\S 262(\mathrm{k})(7)(\mathrm{B})$.

162. See supra, text accompanying notes 25-37.

163. For a description of the controversy and excerpts from the Congressional letters, see Thomas, supra note 32 , at $8-9$.

164. See, e.g., Timmis, supra note 154, at 226-31 (arguing that because of the expense of developing biologics, long exclusivity periods for reference product and first interchangeable, and difficulty of obtaining interchangeable designation, the Biologics Act is unlikely to decrease biologic drugs prices to the degree that Congress intended).

165. See Jonathan D. Rockoff, Knockoffs of Biotech Drugs Bring Paltry Savings, WALL ST. J. (May $5,2016)$ at A1, available at http://www.wsj.com/article_email/knockoffs-of-biotech-drugs-bring-paltrysavings-1462458209-1MyQjAxMTA2NDA1NTkwNDU2 Wj. 


\section{Infectious Diseases (QDIP)}

Coming on the heels of the Biologics Act and in the same Congress as the America Invents Patent Reform Act, the 112th Congress also approved Regulatory Property intended to promote the development and production of drugs to treat so-called "super bugs" that are resistant to ordinary antibiotics. Thus, the rights are granted for antibacterial or antifungal drugs intended to treat serious or life-threatening infections. ${ }^{166}$

Regulatory Property for infectious diseases overflows with acronyms. The bill was called the GAIN Act, an abbreviation for "Generating Antibiotic Incentives Now," and the program is known as QDIP, an abbreviation for "Qualified Infectious Disease Products." 167 Perhaps the acronyms were an attempt to mimic the public relations value of the term "orphan" in the wildly successful Orphan Drug Act, although nothing can quite recapture that magic.

The notion of overflowing also is appropriate to the infectious disease legislation because the program follows a pattern of just adding more. Once a drug is designated as a qualified infectious disease product, the various Regulatory Property benefits for the drug are extended by five years. ${ }^{168}$ Thus, the four or five-year data rights a drug may have if it is a new chemical entity are extended five years to reach a new total of nine or ten years. The three-year data rights a drug may have for performing new clinical trials for improvements on existing drugs (new dosages or new indications) are extended for five years to reach a new total of eight years. And the seven-year marketing rights a drug may have if it is an orphan drug are extended five years to reach a new total of twelve years. The legislation also granted various other benefits for qualified infectious disease products, including fast track approval at the FDA, priority review, and the type of "all hands on board" regulatory assistance enjoyed by orphan drug developers. ${ }^{169}$

\section{Pediatric Studies}

The 112th Congress passed one additional law regarding a form of Regulatory Property related to pediatric drug studies. Regulatory Property for pediatric drug studies was originally created by Congress in 1997 as part of the Food \& Drug Administration Modernization Act, but it had a sunset provision that had been extended twice to an ending date of 2012. ${ }^{170}$ The 112th Congress reauthorized the provision, making it permanent. ${ }^{171}$

166. See Food and Drug Administration Safety and Innovation Act, Pub. L. No. 112-144, § 801, 126 Stat. 993, 1077 (2012) (introducing 21 U.S.C. § 505E).

167. See id.; see Thomas, supra note 32, at 10.

168. See 21 U.S.C. \$ 505E(a); see Thomas, supra note 32, at 11.

169. See sources cited supra note 139; Peter Winter, Antibiotics Resistance Rising; Can New Drugs Keep Pace?, BIOWORLD, https://perma.cc/L32W-ZCWJ.

170. John R. Thomas, Pharmaceutical Patent Law 493 (3d ed. 2015); see Policy Framework for BPCA and PREA in SAFE AND EFFective Medicines fOR ChILdREn: Pediatric Studies Conducted Under the Best Pharmaceuticals for Children Act AND the Pediatric Research EQUITY ACT (Marilyn J. Field \& Thomas F. Boat eds. 2012), https://perma.cc/2862-33PE.

171. See Thomas, supra note 32, at 10. 
With the 1997 start date, the pediatric drug study rights show that Regulatory Property has been created outside of these two major waves. The pediatric drug study law is grouped with the 112th Congress for this Article, however, given that the law was extended during that wave of Regulatory Property activity.

Pediatric clinical trials are more difficult to perform, with problems including complexity of informed consent, changes that occur as children grow, and the difficulty of obtaining accurate and reliable data from children. ${ }^{172}$ As a result, few drugs on the market have been formally tested in children, and doctors lack reliable information on safety and efficacy in this patient population. Congress responded to these concerns with the creation of a new basket form of Regulatory Property intended to encourage companies to perform pediatric clinical trials. The Regulatory Property is granted when a company completes clinical studies of the effects of a drug on children. ${ }^{173}$

Regulatory Rights for pediatric studies have an oddly chameleon-like nature. They can take the form of either marketing rights, data rights, or both. Specifically, the legislation provides that when a company completes pediatric studies, the company will receive a six-month extension of its patent rights and/or its various forms of exclusivity. Thus, a company's orphan drug marketing rights are extended for six months along with its new chemical entity data rights are extended for six months. ${ }^{174}$ If a company has both patent rights and exclusivities, each one is separately extended for six months. ${ }^{175}$ For drugs that have no patent or exclusivity, Congress in 2002 amendments created a system in which the FDA would award contracts to companies willing to engage in pediatric studies. The provision appropriated $\$ 200$ million to pay for these contracts. ${ }^{176}$

The patent extension for pediatric studies does not operate directly as any alteration to the patent at the Patent \& Trademark Office. Rather, it operates as a marketing right, in which the FDA may not approve another drug with the same active ingredient until six months after the original company's patent expires.

Although six months is not a particularly long period of time, the pediatric study rights have aspects that greatly enhance their value. For example, the pediatric rights apply to all formulations and uses of the drug, including those for adults. This expansive application stands in contrast to the rights granted for orphan drugs, rights that apply only for the particular active ingredient and indication of the drug. Thus,

172. See id. at 9 .

173. The FDA must request that a company perform clinical studies, but companies can ask to receive such a request. See Qualifying for Pediatric Exclusivity Under Section 505A of the Federal Food, Drug, and Cosmetic Act: Frequently Asked Questions on Pediatric Exclusivity (505A), The Pediatric "Rule," and Their Interaction, U.S. FOOD AND DRUG ADMIN. [hereinafter "FDA FAQs"], available at http://www.fda.gov/Drugs/DevelopmentApprovalProcess/DevelopmentResources/ucm077915.htm?sour $\mathrm{ce}=$ govdelivery\&amp;utm_medium=email\&amp;utm_source=govdelivery.

174. See Lal, supra note 47 , at 2 .

175. See FDA FAQs, supra note 173. For drugs that have no patent or exclusivity, Congress in 2003 amendments created a system in which the FDA would award contracts to companies willing to engage in pediatric studies. The provision appropriated $\$ 200$ million to pay for these contracts.

176. See BPCA § 3(3)(a)(2) (codified as 42 U.S.C. § 284m(a)(2) (West 2003)); I. Glen Cohen, Therapeutic Orphans, Pediatric Victims: The Best Pharmaceuticals for Children Act and Existing Pediatric Human Subject Protection, 58 FoOD \& DRUG L.J. 660, 668 (2003). 
while a new use patent could be limited to a particular use of the drug, if the company carried out pediatric studies, the FDA could not grant approval to new competitor to make the same drug for any use in any population during the extended period.

Six months may not sound like much, but the right can be worth a great deal. Successful drugs bring in hundreds of millions of dollars a year, and so-called Blockbuster drugs bring in more than a billion dollars a year. ${ }^{177}$ Thus, the ability to keep all others out of the market for an additional six months can be extraordinarily valuable. $^{178}$

In addition, the six-month right can be strung together with other rights to enhance the overall value. For example, a company could make a qualified infectious disease product (five years of data rights) that qualifies as a new chemical entity (five years of data rights) and do pediatric studies on the drug (six months of extension). Although each program alone looks relatively small, added together, the company would have ten-and-a-half years of data exclusivity. ${ }^{179}$

The pediatric studies program has, indeed, encouraged numerous companies to conduct clinical studies of safety and efficacy in children. It is unclear, however, whether the breadth of the rights is proportionate to the societal benefits. With most Regulatory Property, a company receives benefits in exchange for success, that is, when a drug is approved or a new chemical or use is identified. In contrast, companies receive the pediatric study rights even when the studies are not successful in demonstrating safety and efficacy in children, although even negative effects can be used to add warning, contraindications and precautions to the label. ${ }^{180}$ In addition, scholars have raised concerns that the benefits have created a "race to the bottom" because they do not require that the studies have been conducted according to commonly accepted scientific and ethical standards. ${ }^{181}$

\section{Rare Pediatric Diseases}

In the realm of benefits for pediatric diseases, the 112th Congress created an additional form of benefit. As part of the Food and Drug Safety Administration Act of 2012, Congress created a program in which companies that receive approval for drugs to treat certain rare pediatric diseases receive a voucher for priority review of the drug at the FDA. ${ }^{182}$ This voucher can be used for priority review of another drug

177. See Feldman \& Frondorf, supra note 40, and text accompanying notes 16-19 (discussing the value of delaying generic entry by six months in the context of pay-for-delay settlements); Herder, supra note 92, at 242 (defining blockbuster drugs).

178. See text accompanying notes 196-197, infra (explaining tradeable rights that merely accelerate FDA approval by four months, and describing sales of those rights for \$125 million and \$350 million); see also Cohen, supra note 176, at 665-66 (noting that for ten of the first 36 drugs to receive pediatric study rights had sales that exceeded $\$ 200$ million in six months, with two of them exceeding $\$ 800$ million and two exceeding \$1 billion).

179. See Thomas, supra note 32 , at 11 (setting out this example).

180. See Thomas, supra note 32 , at 10.

181. See Cohen, supra note 176 , at 661 .

182. See P.L. No. 112-144, § 908 (2012) (codified as 21 U.S.C. § 360ff). The notion of priority vouchers was initially proposed in the following academic article: David Ridley, Henry Gabowsli, \& Jeffery Moe, Developing Drugs for Developing Countries, HeALTH AFFAIRS (2006), available at 
by the same company or sold to another company. ${ }^{183}$

With the voucher, the FDA is obligated to review a company's application for approval of a new drug within six months. ${ }^{184}$ For traditional reviews, the FDA typically takes at least ten months or more. Although expediting review by as little as four months may not sound like much, the vouchers are highly valued. Studies estimate that the vouchers are worth hundreds of millions of dollars, and, in fact, AbbVie recently purchased one for $\$ 350$ million. ${ }^{185}$

Although the program for pediatric priority review vouchers was reauthorized in 2013, a Government Accountability Office ("GAO”) report on the program in 2015 noted that FDA officials do not support continuation of the program. ${ }^{186}$ The officials expressed concern that the transferable nature of the vouchers interferes with the agency's ability to set public health priorities in reviewing treat serious conditions or provide significant improvements in safety or efficacy. ${ }^{187}$

For example, in theory, a company could buy a voucher for a drug that has minimal public benefit in that it represented only minor differences over existing treatments. The drug might have great benefit to the company, however, if it could be combined with other exclusivities and life cycle management techniques to secure market position in a widely used product. ${ }^{188}$ The company could then jump to the front of the line, passing over drugs that show significant benefits for health priorities.

Regardless of the level of invention or health priorities, tradeable vouchers can be used as a competitive tool to beat other pharmaceutical companies to market. For example, the pharmaceutical company Sanofi used a pediatric priority review voucher to beat its competitor in a race to first market a new form of cholesterol drug. ${ }^{189}$ Sanofi's competitor was able to reach the market first in Europe, but the

http://content.healthaffairs.org/content/25/2/313.abstract; see also Alexander Gaffney \& Michael Mezher, Regulatory Explainer: Everything You Need to Know About FDA's Priority Review Vouchers, REGULATORY AFFAIRS PROFESSIONALS SOCIETY (July 2, 2015) (crediting Grabowski et. al. with the idea for priority vouchers and describing the system), available at http://www.raps.org/RegulatoryFocus/News/2015/07/02/21722/Regulatory-Explainer-Everything-You-Need-to-Know-About-

FDA $\%$ E2\% $80 \% 99$ s-Priority-Review-Vouchers/.

183. Id.

184. The FDA has asserted that the voucher programs do not guarantee review within that period of time, but only that the drug can be entered into the group entitled to expedited review of which the FDA must complete $90 \%$ of them in the time specified. See Gaffney \& Mezher, supra note 182 (citing Guidance for Industry Tropical Disease Priority Review Vouchers, U.S. FoOD \& DRUG ADMIN. 6 (2008), http://www.fda.gov/downloads/Drugs/.../Guidances/UCM080599.pdf).

185. See Aaron S. Kesselheim, Drug Development for Neglected Diseases-The Trouble with FDA Review Vouchers, 359 N. ENGL. J. OF MED. 1981 (2008) (discussing the value of priority vouchers for tropical diseases); Chelsey Dulaney, United Therapeutics Sells Priority-Review Voucher to AbbVie for $\$ 350$ Million, WALL ST. J. (Apr. 19, 2015), available at http://www.wsj.com/articles/united-therapeuticssells-priority-review-voucher-to-abbvie-for-350-million-1439981104.

186. Rare Diseases: Too Early to Gauge Effectiveness of FDA's Pediatric Voucher Program, GOVERNMENT ACCOUNTABILITY OFFICE (Mar. 2016) (overview) (hereinafter "GAO Report").

187. Id.

188. See FELDMAN, supra note 19, at 170-78 (describing product hopping techniques); Feldman \& Frondorf, supra note 40, at 527-33 (describing product hopping techniques and using weak follow-on patents, forms of "evergreening").

189. Use of Rare Pediatric Disease Priority Review Voucher; Approval of a Drug Product, FooD \& 
priority voucher allowed Sanofi to jump ahead in the U.S. ${ }^{190}$ Sales of this new class of drugs are expected to reach into billions of dollars a year, and the first company to reach the market in the U.S. usually enjoys sales and marketing momentum, as well as advantages in the payment and reimbursement system. ${ }^{191}$

The GAO report concluded that it is too soon to gauge the effectiveness of priority vouchers for rare pediatric diseases. ${ }^{192}$ The program is set to expire in $2016 .{ }^{193}$

In short, the Regulatory Property created for pediatric studies and rare pediatric diseases follows the pattern of all of the Regulatory Property created by the 112th Congress in 2011-2012. The pattern can be described simply as adding more.

\section{Proliferation-Beyond Passage of the Major Generic Regimes}

The two sections above chronicled the myriad benefits created at the same time as Congress passed the two major generic regimes. In addition, other forms of Regulatory Property have begun to proliferate. Some of these are simply extensions or adjustments of the existing regimes described above. ${ }^{194}$ In 2014, for example, the FDA expanded its definition of new chemical entity to include drugs that have a combination of active ingredients, as long as the FDA has not previously granted approval to at least one active ingredient. ${ }^{195}$ The FDA's definition was further expanded in 2015-granting new chemical entity status to isolated components of a drug when the FDA had previously approved the full mixture - when a court vacated and remanded an administrative decision to the contrary. ${ }^{196}$

Entirely new regimes and proposed regimes are popping up, as well.

DRUG Admin. Notice (Aug. 24, 2015), https://perma.cc/VN39-D3AU; Alexander J. Varond, Priority Review Voucher Updates: Valuation, Eligibility, Reauthorization, FDA LAW BLOG (Aug. 30, 2015), https://perma.cc/MM89-67JM.

190. See European Commission Approves Amgen's New Cholesterol-Lowering Medication Repatha $^{\text {TM }}$ (evolocumab), The First PCSK9 Inhibitor To Be Approved in the World, for Treatment of High Cholesterol, AMGEN (July 21, 2015), http://investors.amgen.com/phoenix.zhtml?c=61656\&p=irolnewsArticle\&ID=2069405; Varond, supra note 189.

191. Varond, supra note 189.

192. See GAO Report, supra note 186.

193. Id. at 2 n.3.

194. See, e.g., text accompanying notes 83-84; see Thomas, supra note 32, at 9-10 (describing amendments to the pediatric studies legislation); Cohen, supra note 176 (same). In the same vein, in 2015 Congress passed the Improving Regulatory Transparency for New Medical Therapies Act, which was signed into law later that year. The Act relates to drugs that are regulated by the Drug Enforcement Administration ("DEA") because of their potential for abuse and ensures that the exclusivity periods of new drugs potentially subject to the DEA program are not delayed by the time it takes for the DEA to make a scheduling decision. See Improving Regulatory Transparency for New Medical Therapies Act, H.R. 639, 114th Cong. (2015).

195. See David Hoffmeister et al., New Exclusivity for Fixed-Dose Drugs Will Help Small Cos., LAW360 (Apr. 28, 2014), https://perma.cc/Y59H-PLB7 (citing Guidance for Industry: New Chemical Entity Determinations for Certain Fixed-Combination Drug Products, U.S. FoOD \& DRUG ADMIN. 7 (Feb. 21, 2014), https://perma.cc/K6W3-7B2R.

196. See Hoffmeister et al., supra note 54 (discussing the change in apparent response to the District Court for the District of Columbia's ruling regarding Amarin's drug Vascepa); Amarin Pharm. Ir. Ltd. v. FDA, 106 F. Supp. 3d 196 (D.C. Cir. 2015). 


\section{Tropical Diseases}

Although somewhat of an outlier, the tropical disease voucher program follows the same pattern of passage at the same time as legislation that would restrict a drug company's ability to block generic entry. Specifically, in 2007, Congress passed legislation limiting the ability of brand-name drug companies to use the citizen petition process at the FDA to obstruct generic entry. ${ }^{197}$ The tropical disease voucher program passed in the same year.

The example is somewhat of an outlier, given that the citizen petition anti-abuse provisions were part of a larger set of amendments to the Food, Drug, and Cosmetic Act, which contained other provisions supported by the pharmaceutical industry. ${ }^{198}$ Nevertheless, once again when Congress passed legislation to help generic entry, it also passed legislation with new pharmaceutical exclusivities.

Thus, similar to the priority vouchers for pediatric studies, Congress approved another set of tradeable vouchers as part of amendments to the Food, Drug, and Cosmetic Act in 2007. ${ }^{199}$ These vouchers are given for approval of neglected tropical diseases that disproportionately affect poor populations in developing countries. ${ }^{200}$ The legislation lists specific diseases such as malaria, tuberculosis, leishmaniasis and others, and both Congress and the FDA have added more diseases to the list across time. ${ }^{201}$

Tradeable vouchers, whether for tropical diseases or for rare pediatric conditions, can garner sky-high prices on the open market. For example, in 2014, Knight Therapeutics sold a voucher to Gilead for $\$ 125$ million. ${ }^{202}$ Similarly, in 2015, United Therapeutics sold a voucher to AbbVie for $\$ 350$ million. ${ }^{203}$ These eye-popping numbers offer a glimpse of the value of the Regulatory Property that Congress has

197. Food and Drug Administration Amendments Act of 2007, Pub. L. 110-85, 121 Stat. 823 (2007) (codified in scattered sections of 21 U.S.C.); see also Michael Carrier and Daryl Wander, Citizen Petitions: An Empirical Study, 34 CARDOZo L. Rev. 249, 263 (2012) (discussing testimony of Senator Edward Kennedy that, "[t]he citizen petition provision is designed to address attempts to derail generic drug approvals. Those attempts, when successful, hurt consumers and the public health") 153 CONG. REC. 25,047 (2007). For a discussion of the legislation and an empirical analysis of its failure to stop the targeted behavior, see Robin C. Feldman, Evan Frondorf, \& Andrew K. Cordova, Empirical Evidence of Drug Pricing Games-A Citizen's Pathway Gone Astray, (forthcoming), available at http://papers.ssrn.com/sol3/papers.cfm?abstract_id=2833151.

198. See Jeffrey L. Fox, New Law broadens FDA safety authority, renews user fees, 25 NATURE BIOTECHNOLOGY 1189-90 (2007) http://www.nature.com/nbt/journal/v25/n11/full/nbt1107-1189.html (last visited Sept. 15, 2016).

199. See Food and Drug Administration Amendments Act of 2007, $\S 1102$ (codified at 21 U.S.C. $\S$ 524) (2007)).

200. See Aaron S. Kesselheim, Drug Development for Neglected Diseases-The Trouble with FDA Review Vouchers, 359 N. ENGL. J. OF MED. 1981-83 (2008).

201. Id.

202. See Knight Sells Priority Review Voucher to Gilead, Knight (Nov. 19, 2014) https://perma.cc/TZX6-X5K8 (noting sale of voucher obtained through tropical disease program); see also Ed Silverman, How Much? Gilead Pays \$125M For an FDA Priority Review Voucher, WALL ST. J. (Nov. 19, 2014), https://perma.cc/CL2C-PETG.

203. United Therapeutics Corporation Agrees to Sell Priority Review Voucher to AbbVie for $\$ 350$ Million, UNITED THERAPEUTICS (Aug. 19, 2015), https://perma.cc/6328-6JJ7 (noting sale of voucher obtained through rare pediatric disease program); see also Dulaney, supra note 185. 
been continually creating for the past thirty years. One must ask who is paying the bill in the end, and most likely it is the purchaser. The hundreds of millions of dollars a company spends to jump the approval line are folded into the eventual price of the drug, or into the price of other drugs the company gets to market.

In analyzing the economic effects of vouchers, it is important to note that spending high sums to acquire these vouchers-whether one develops a drug for a favored category or purchases a voucher from another company - is a form of a gamble. The voucher may bring a speedier response, but it does not guarantee the FDA will approve the drug. For example, Novartis used a voucher to accelerate review of its biologic drug for the treatment of gouty arthritis, but the FDA denied approval of the drug. $^{204}$ Any sums that a company spends to try to get various drugs to market are likely to be folded into pharmaceutical prices. If the drug is successful, the cost will be folded into the price of that drug; if the drug is unsuccessful, the cost will be folded into the price of other drugs the company brings to market. ${ }^{205}$ One might ask whether it makes good policy sense to create a system that encourages companies to drive up drug prices as they gamble on efforts to beat each other to market.

Only a limited number of vouchers have been granted, and the legislation specifically limits the number of some types. ${ }^{206}$ These vouchers can be sold and resold an unlimited number of times, however, which amplifies the size of the secondary market for vouchers and the potential economic effects. ${ }^{207}$

The tropical disease voucher program caused a flurry of concern, featuring pharmaceutical bad boy, Martin Shkreli. Shkreli initially enraged lawmakers and commentators as CEO of Turing Pharmaceuticals when the company raised the price of an antimalarial drug used for treatment of infections in HIV patients from $\$ 13.50$ per pill to $\$ 750$ per pill. ${ }^{208}$ In the case of tropical diseases, Shkreli lead a group of

204. See Gaffney \& Mezher, supra note 182.

205. In explaining drug pricing and the need to recoup costs, pharmaceutical companies and industry groups frequently fold the cost of unsuccessful drug attempts into the cost of drugs that finally succeed. See, e.g., Reichman, supra note 12, at 11 (explaining that the oft quoted price tag for successful drug development of $\$ 800,000$ - $\$ 1$ billion includes a "risk premium" to recoup the costs of failed drug profits and failed clinical tests); Wayne Winegarden, The Economics of Pharmaceutical Pricing, PACIFIC RESEARCH INSTITUTE 17 (2014), https://perma.cc/QH7Y-FNCJ (noting how only two out of ten marketed drugs result in revenue that exceeds research and development costs, resulting in high drug prices to recoup costs); Andrew Pollack, Drug Prices Soar, Prompting Calls for Justification, N.Y. TIMES (July 23, 2015), https://perma.cc/3RZ7-5PS7 (citing an official from the Pharmaceutical Research and Manufacturers of America as saying that, due to money spent on failed drugs, it is misleading to look only at the development costs for one drug); Ben Hirschler, GlaxoSmithKline Boss Says New Drugs can be Cheaper, REUTERS (Mar. 14, 2013), https://perma.cc/K3SG-TW44 (quoting chief executive of GlaxoSmithKline as saying that the one billion dollar price tag claimed for development of one drug is "one of the great myths of the industry" since it includes money spent on drugs that fail).

206. For an easily accessible explanation of the voucher systems along with lists of the vouchers granted through summer of 2015, see Gaffney \& Mezher, supra note 182.

207. Originally, rare pediatric drug vouchers could be re-traded, but tropical disease vouchers could only be sold once. A 2014 Congressional amendment to the tropical disease program clarified that the legislation allowed for unlimited transfers. See Adding Ebola to the FDA Priority Review Voucher Program Act, S. 2917, 113th Cong. (2014); Gaffney \& Mezher, supra note 182.

208. See Feldman \& Frondorf, supra note 40, and text accompanying notes 193-206 (describing the Turing saga and techniques the company used to improperly block competition). Shkreli later resigned his post as CEO of Turing after being arrested on charges of securities fraud for activities at a prior 
investors who purchased a company with rights to a drug used to treat Chagas disease, which is caused by a parasite and is found most commonly in South and Central America. ${ }^{209}$ Although the drug is already in common use in those countries, it has never been approved for sale in the United States. Shkreli set out his intent to apply for FDA approval of the drug in the United States, garner a tradeable voucher, and then sell that voucher. If the move is successful, the company would receive a voucher in exchange for a drug that is already being widely used to treat the particular tropical disease.

The idea of garnering Regulatory Property with old medicines is not unique to Martin Shkreli or to the tropical disease voucher program. For example, one of the original forms of Regulatory Property was created for approval of new chemical entities. $^{210}$ The legislative language refers to the introduction of entities whose active ingredients have not been approved by the FDA and references the original Food, Drug, and Cosmetic Act of 1938. ${ }^{211}$ As a result, drugs whose active ingredients have been used in medication since before that time can be introduced as "new" chemical entities, thereby receiving the benefits.

Other forms of Regulatory Property have emerged either through Congressional legislation or FDA mandate.

\section{Unapproved Drugs}

In a form of amnesty proposal, the FDA launched an initiative to encourage those who make old drugs - those that have been sold since before implementation of the current FDA drug approval process - to come in from the cold. ${ }^{212}$ At least one company working with the FDA under the Unapproved Drug Initiative, was able to garner significant exclusivities and market advantage. Specifically, the maker of an old gout remedy, colchicine, received three years of data rights for new clinical studies that consisted, in part, of one week of testing 185 patients at a reduced dosage. $^{213}$ The reduced dosage had been recommended by one of the major rheumatology societies as well as in a study published by researchers twenty years before. $^{214}$

In addition to benefits for "new" clinical studies, the company also received seven years of marketing rights as an orphan drug indication for the treatment of a familial Mediterranean fever. ${ }^{215}$ As described above, drugs do not need to be new in order to receive benefits for an orphan drug indication, and coming in from the cold allowed the company to benefit from that provision, as well. As a final happy circumstance

company. See Robert Langreth, Shkreli Resigns as Turing CEO After Arrest on Securities Fraud, BLOOMBERG (Dec. 18, 2015), https://perma.cc/D3DM-5GS6.

209. See Andrew Pollack, Martin Shkreli's Latest Plan to Sharply Raise Drug Prices Prompts Outcry, N.Y. TIMES (Dec. 11, 2015), https://perma.cc/TK25-77FR.

210. See supra text accompanying notes 71-79.

211. See 21 CFR $\S 314.108$ (a) (2012).

212. See Thomas, supra note 32 , at 12 .

213. See Kesselheim \& Solomon, supra note 102.

214. See id.

215. See id. 
for the company, the FDA announced its intention to act against other unapproved makers of the product. ${ }^{216}$ As the sole remaining provider, the company raised its price from $\$ .09$ a pill to $\$ 4.85$ per pill. ${ }^{217}$ Scholars projected that with the price increase, Medicare and Medicaid spending alone would rise from $\$ 1$ million a year on the drug to $\$ 50$ million a year. ${ }^{218}$

The FDA's Unapproved Drugs Initiative does not create its own form of Regulatory Property, but the agency can use the program in ways that are quite helpful for applicants in gaining rights. In short, coming in from the cold can prove quite warm and lovely, indeed.

\section{The Trans-Pacific Partnership}

The proliferation of Regulatory Property has not been confined within the boundaries of the U.S. There have also been efforts to expand the web of regulatory exclusivities abroad, offering monopoly protection to U.S. pharmaceutical companies in their international dealings. Such efforts have been showcased in recent negotiations over the Trans-Pacific Partnership ("TPP”). As the TPP developed, American drug makers fought hard to take the exclusivities they have enjoyed at home and directly export them overseas. ${ }^{219}$ They largely succeeded, receiving several favorable provisions in the TPP's 75-page intellectual property chapter, such as five years of data exclusivity for new chemical entities and three years of protection for new clinical studies. ${ }^{220}$ U.S. data and marketing exclusivities were not adopted into the TPP agreement without resistance, however. In particular, the length of data protection for new biologics became a source of great

216. See Thomas, supra note 32, at 12. The FDA has since amended its guidelines on actions, which include consideration of market conditions in choosing priorities for enforcement actions. See FoOD \& DRUG ADMIN., Guidance for FDA Staff and Industry: Marketed Unapproved Drugs - Compliance Policy Guide (2011) (including the 2011 amendment and noting that marketing conditions may be considered), https://perma.cc/P6FH-MR44.

217. See Thomas, supra note 32, at 12 .

218. See Kesselheim \& Solomon, supra note 102.

219. See PhRMA Urges President Obama to Secure an Ambitious Trans-Pacific Partnership Agreement, PHRMA (May 8, 2012), https://perma.cc/4KDJ-87MV (describing a letter sent by industry representatives to President Obama, urging "the adoption of strong IP protections by all countries in the TPP"); IP Protections Critical to Development of New, Life-Saving Medicine, PHRMA (Mar. 4, 2013), https://perma.cc/37SC-2XWA (quoting PhRMA representative, "A weak IP framework within TPP would create uncertainty at a time when we need to be doing more to champion researchers and innovators who rely on strong protections" and emphasizing biologics in particular); Jay Taylor, Protecting the Key to a Successful TPP, PHRMA (Dec. 20, 2013), https://perma.cc/4N2C-BRYQ (arguing that "a TPP agreement that includes IP protections at least as strong as current U.S. law would have a tremendously positive effect on participants"); The Trans-Pacific Partnership and Innovation in the Bioeconomy: The Need for 12 Years of Data Protection for Biologics, BIO: BIOTECHNOLOGY INNOvation ORGANIZATION, https://perma.cc/3YH6-6WTB (describing a letter and white paper submitted to the U.S. Trade Representative urging strong intellectual property protection, including twelve year data protection for biological products); Adam Behsudi \& Brett Norman, Big Pharma seeks special trade deal, POLITICO (June 5, 2015), https://perma.cc/CF7U-N9QR.

220. See Trans-Pacific Partnership, at 18-26, https://perma.cc/DGG4-VCSP; see also Baker, supra note 12 , at 3 . 
controversy. ${ }^{221}$ As described previously, the period of data rights afforded to original biologic drug makers in the U.S. is unusually long: twelve years, and the marketing protection portion is four years. ${ }^{222}$ Industry representatives pushed hard in TPP for twelve years of full marketing protection. ${ }^{223}$ Opponents sought a much shorter period of five years, concerned about the potential for long protection periods to stymie access to much-needed medications in poor and developing countries. ${ }^{224}$ Eventually, after several years of debate, a compromise of eight years was reached. ${ }^{225}$ This includes five years of actual protection and the potential that the final three years could be satisfied if market conditions are such that protection is conferred.

Depending on how one looks at it, the TPP could be considered either longer or shorter than US protection for biologics. Comparing pure marketing protection to pure marketing protection, the TPP is longer. U.S. marketing protection for biologics is only four years while the TPP is eight.

If one looks at total protection from all sources, however, protection is shorter for biologics in the TPP than in the US. The total U.S. protection, including data rights, is twelve years, while the total TPP protection is eight years. The question may turn on the extent to which one believes there is any difference between data rights and marketing rights. If the two are equivalent, then TPP is weaker. If one believes marketing rights are stronger, then the TPP has longer protection that the U.S.- - eight years rather than four.

Part of the difficulty in achieving consensus among TPP members stems from the wide variations in domestic policy on Regulatory Property. While some countries, such as Canada and Australia, have regimes somewhat similar to that of the U.S., other countries, like Vietnam and Malaysia, have much weaker protections or no protection at all. ${ }^{26}$ That the U.S. has perhaps the most extensive and powerful Regulatory Property regime of all TPP countries speaks to the power of the domestic

221. The protection for biologics was particularly contentious because it was a novel proposition, outside of the norm in length, and considered to be unnecessary to create incentives for innovation. See Tim Fernholz, Under the TPP, America's insanely high drug prices will be an unappreciated export, QUARTZ (Nov. 9, 2015), https://perma.cc/D8TX-9ZPE. Though nearly all recent U.S. free trade agreements contain intellectual property protections, and many contain marketing/data exclusivities of some kind, the inclusion of an extended period of protection for biologics was a first. See Lee Branstetter, TPP and the Conflict Over Drugs: Incentives for Innovation Versus Access to Medicines, in ASSESSING THE TRANS-PACIFIC P'ShIP VOLUME 2: INNOVATIONS IN TRADING Rules 20, 22 (Jeffrey J. Schott \& Cathleen Cimino-Isaacs eds. 2016), https://perma.cc/5WWS-TZ89.

222. See Biologics Act, supra notes 146-55.

223. See supra text accompanying note 219.

224. Branstetter, supra note 221, at 21; Lisa De Bode, Trade deal is a big win for Big Pharma, health rights advocates say, AL JAZEERA (Oct. 5, 2015), https://perma.cc/HNM2-DK9B (quoting Doctor Without Borders calling TPP "the worst trade agreement for access to medicines in developing countries" in history).

225. Technically, the TPP guarantees a baseline of five years of standard data protection, with a provision allowing countries to use "other measures" to satisfy the three additional years of market protection. See Robert A. Rogowsky, Intellectual Property in the Trans-Pacific Partnership, 22 BROWN J. WORLD AFFAIRS 123, 131; Baker, supra note 12, at 4.

226. See Ryan Davis, TPP Aims to Spread US-Style IP Protections Overseas, LAW360 (Nov. 5 , 2015), https://perma.cc/CD56-94XP; Rogowsky, supra note 225, at 132. 
pharmaceutical and biotechnology industries in influencing legislative activity. ${ }^{227}$ In fact, lingering frustration over failure to achieve a twelve-year provision may jeopardize passage of the TPP in the U.S. Congress. ${ }^{228}$ Given the trend of new forms of Regulatory Property materializing in response to industry discontent, drug companies' disappointment with the outcome of TPP negotiations ${ }^{229}$ may portend further expansion of Regulatory Property within the U.S.

\section{Proposals: Abuse-Deterrent Opioids, Combination Therapies, Dormant Therapies, Diagnostic Tests}

As Regulatory Property becomes increasingly popular, numerous new forms are being proposed by legislators. The most recent bill relates to abuse-deterrent opioids and is called the COMBAT Act. Following the "just add more" pattern, the bill would add one year to the three-year data rights for new clinical studies for abusedeterrent opioids. $^{230}$ It would also add two months to the marketing rights for first filing generic drugs (with a patent challenge to the branded drug) that are abusedeterrent opioids, increasing that benefit from six months to eight months. ${ }^{231}$

Other bills have appeared recently in Congress without passage, although they could be resurrected in the future. These have included the Life-Threatening Diseases Compassion Through Combination Therapy Act of 2012, which would have extended by six months any Regulatory Property granted to the company for the drug. ${ }^{232}$

Taking a different approach, the MODDERN Cures Act, which stands for the Modernizing Our Drug \& Diagnostics Evaluation and Regulatory Network Cures Act, ${ }^{233}$ would shift the emphasis for pharmaceutical companies away from the patent

227. See Thomas J. Bollyky, A Dose of TPP's Medicine: Why U.S. Trade Deals Have Not Exported U.S. Drug Prices, Council On Foreign Relations Working PaPer (2016), at Table 1, available at http://papers.ssrn.com/sol3/papers.cfm?abstract_id=2755754 (charting out existing pharmaceutical rules in the TPP countries and visually demonstrating the extent of U.S. protections compared to others).

228. See Rogowsky, supra note 225, at 125 (noting strong rejection of the TPP by Republicans in Congress due to failure to obtain biologics concession) and at 132 (noting that Senator Orrin Hatch has established that he will oppose the TPP if it does not include twelve-year exclusivity for biologics); Susan Cornwell, House Speaker Ryan: No point in lame duck vote on TPP deal, ReUTERS (Aug. 4, 2016), https://perma.cc/Z4CD-HYKS (describing House Speaker Paul Ryan's comment that the Obama administration has to "renegotiate some pieces" of the TPP, including the biologics provision, "if they have any hope or chance of passing it").

229. Nicole Gray \& Sy Mukherjee, TPP trade deal reached, BIO \& PhRMA unhappy with drug patent compromise, BIOPHARMADIVE (Oct. 5, 2015), http://perma.cc/2KDW-QHUX; BIO Statement on Data Exclusivity Provisions Within the Trans-Pacific Partnership, BIO: BIOTECHNOLOGY INNOVATION ORGANIZATION (Oct. 4, 2015), http://perma.cc/VL3Q-JTVZ (quoting BIO President and CEO Jim Greenwood, "We are very disappointed in reports from Atlanta that suggest Trade Ministers have failed to include 12 years of data exclusivity for biologics in the Trans-Pacific Partnership (TPP) agreement.").

230. See Curb Opioid Misuse by Advancing Technology Act of 2016, H.R. 5127, 114th Cong. § 2(a) (2016)

231. See id.

232. See Life-Threatening Diseases Compassion through Combination Therapy Act of 2012, H.R. 6502, 112th Cong. (2012).

233. See Modernizing Our Drug \& Diagnostic Evaluation and Regulatory Network Cures Act of 2013, H.R. 3116, 113th Cong. (2013). 
system and toward Regulatory Property. ${ }^{234}$ The bill, which has been reintroduced in various forms since $2011,{ }^{235}$ would provide fifteen years of marketing rights for certain drugs. $^{236}$ Companies could opt into the system, but would have to relinquish patent rights that extend past the fifteen years. ${ }^{237}$ Criticisms of the proposal include concerns that a company would only have to relinquish prior patent rights, not patents granted after FDA approval. ${ }^{238}$ This would allow for continuation of life-cycle management techniques in which companies file for patents on new uses, methods of manufacture, and variations of a drug in order to extend the time in which the drug is protected by patents. ${ }^{239}$

Finally, one commentator has suggested that legislators in 2016 will consider a bill to grant Regulatory Property for diagnostic tests. ${ }^{240}$ In addition to legislative proposals, scholars have advanced numerous proposals to create various forms of Regulatory Property for aspects of the pharmaceutical industry. These have included ones for new uses of existing drugs, ${ }^{241}$ product safety testing after FDA approval, ${ }^{242}$ human gene sequences, ${ }^{243}$ ideas described in academic research papers, ${ }^{244}$ as well as doubling the length of all Hatch-Waxman data and marketing rights to achieve ten to fourteen years of protection. ${ }^{245}$

In short, numerous forms of Regulatory Property have been created over the last thirty years. Moreover, members of Congress and the FDA increasingly reach for Regulatory Property as a solution to various problems. For a chart summarizing each of the existing forms, see Appendix A.

As society creates this complex web of regulatory benefits, it is important to analyze where the costs fall and whether we have confidence that the programs are sufficiently operating in the service of the intended goals. Approaching these questions, however, requires understanding how all of these various benefits interact with each other as they are linked together like the complex biological/disease

234. See Thomas, supra note 32, at 13; see also Morris, supra note 51.

235. See, e.g., Dormant Therapies Act of 2014, S. 3004, 113th Cong. (2013); MODDERN Cures Act of 2013, H.R. 3116, 113th Cong. (2013).

236. See Thomas, supra note 32 , at 13 .

237. See id.

238. See Senators Call for 15 Years of Marketing Exclusivity for Some New Drugs, REGULATORY AFFAIRS PROFESSIONALS SOC'Y (Dec. 12, 2014), http://perma.cc/7FBF-8BNY.

239. See, e.g., FELDMAN, supra note 19, at 70-77 (describing evergreening techniques); C. Scott Hemphill \& Bhaven N. Sampat, Evergreening, Patent Challenges, and Effective Market Life in Pharmaceuticals, 31 J. HEALTH ECON. 327, 336 (2012) (testing evergreening theories through data on generic entry and finding that lower quality later expiring patents disproportionately draw patent challenges).

240. See Hoffmeister, et al., supra note 54.

241. See Eisenberg, supra note 125.

242. See Leslie Kushner, Note, Incentivizing PostMarketing Pharmaceutical Products Safety Testing with Extension of Exclusivity Periods, 19 FordHAM InTELL. ProP. MEdiA \& ENT. L.J. 519, 51920. (2009).

243. See Dolin, supra note 51.

244. See Eller, supra note 122.

245. See Benjamin N. Roin, Unpatentable Drugs and the Standards of Patentability, 87 TEX. L. REV. 503, 564-68 (2009). 
processes society hopes to treat. ${ }^{246}$ Only by conceptualizing the entire group as a single, interrelated organism can we hope to analyze and evaluate the cost, impact, and effectiveness of the Regulatory Property society continually grants.

\section{CONCEPTS FOR A UNIFIED WHOLE}

As outlined in the section above, society has created the system of Regulatory Property by accretion. Rather than having a coherent conceptual plan, Congress has added individual pieces here and there across time, often in conjunction with legislation that was difficult for the pharmaceutical industry to swallow. The result is a tangled beast that is at various points quasi-patent, quasi-trade secret, and quasiproperty.

What can be made of the strange nature of Regulatory Property? Does its variable form provide a more efficient method of surgically targeting the evolving problems of incentivizing life science innovation $?^{247}$ Or does its variability simply enhance the negative externalities created by the system, whether those externalities are (1) economic loss from the transaction costs of an enormously complex system; (2) loss of oversight by legislators, competition authorities, and the public due to the system's opacity; or (3) leakage within the system as its complexity allows market actors to maneuver a way that undermines society's intended goals?

Mismatch between society's intended goals and the results of the system could occur in multiple forms, and the problems can be far more subtle than simple failure to incentivize new drugs or treatments. In some circumstances, society may be receiving value through the program, but that value may be insufficient for the benefit conferred. For example, a company may receive an exceedingly valuable right in exchange for a minor improvement on existing treatments or the return to a company for an innovative advance may, nonetheless, be far greater than Congress contemplated. $^{248}$ Even if the return is appropriate to the cost society is paying, that cost may be beyond our societal capacity. Your family would be far safer if you drove them in a Sherman tank, for example, but the cost may not fit comfortably within the household budget.

246. In 2012, the FDA established an Exclusivity Board to engage in oversight and recommendations in the interests of clarity and consistency, particularly for individual decisions. See CDER Exclusivity Board, U.S. FOOD \& DRUG ADMIN., http://perma.cc/DH8A-BBMK. The Board appears to have been established in response to industry concerns about a denial of benefits in a particular case. See Kurst R. Karst, "New” CDER Exclusivity Board Focuses on Clarity and Consistency of Exclusivity Decisions, FDA LAw BLOG (Nov. 6, 2012), http://perma.cc/G8FJ-3Y5C. Thus, the Board appears more likely to be focused on consistency in granting benefits, rather than having a mandate to ask why the exclusivities exist in their current forms.

247. Cf. Morris, supra note 51, at 22 (noting that FDA expertise can tailor exclusivities in a way that can never be achieved in the one-size-fits-all patent system); see Thomas, supra note 32, at 15 (noting that international agreements related to patents such as TRIPS require neutrality with respect to the patent system while exclusivities give Congress more flexibility for stimulating particular forms of private activity).

248. Cf. Reichman, supra note 12, at 43 (expressing concern that exclusivities granted for new clinical trials merely generate improvements upon existing technical know-how without adding a new inventive step to prior art). 
In other circumstances, the costs of the new drug may be borne, not by the patients who use the drug, but by the patients who use an entirely different drug. In other words, there can be an unintended taxation of people with one type of disease for the benefit of people with another type of disease. For example, when a company treating a rare form of cancer transfers a tradeable right to a company treating Alzheimer's disease, the Alzheimer's company is likely to raise its drug price to compensate for buying the voucher. Thus, the Alzheimer's patients are partly bearing the costs of developing a drug for cancer. In addition, the value of blocking competition for a broad market like Alzheimer's may be quite great, resulting in a super high price for the tradeable voucher such that the return to the cancer drug company that far exceeds the value added for the cancer patients. In that case, one has unintended taxation of the hypothetical Alzheimer drug patients combined with a benefit for the cancer company that exceeds the value created for society.

In other circumstances, society may have intended to incentivize exploration into new drugs, with all of the spillover benefits that may occur for other diseases when new compounds are discovered. Instead, the program incentivized repurposing of existing or extremely old drugs.

Finally, in some circumstances, a program may be too successful. Society could get the innovation it hoped for in a specialized area of health concern. Nevertheless, the cost could be diversion of energy from other health concerns to an extent far greater than anticipated or desired. Society would be unlikely to approve a diversion of all health care research into a single area, for example cancer treatment, yet the various programs may, in concert, have that effect. ${ }^{249}$

In exploring valuation problems with Regulatory Property, the problem is not with the value of each cause. Drugs for antibiotics-resistant bacteria, cancer treatments, and abuse-deterrent opioids are of great value to society. The problem arises when there is a mismatch of the value created with the costs and effectiveness of the various programs. The challenge for analyzing Regulatory Property in this manner involves obtaining a clear picture of the costs.

All of the questions and potential problems outlined above deserve empirical and theoretical exploration; recognizing the system as an interconnected whole, however, is a prerequisite for those explorations. Most important, without a coherent theoretical framework, one cannot intelligently shape the development of the system and test its success. The remainder of this section provides a general theoretical framework for Regulatory Property and suggests benchmarks to use in establishing and evaluating it. Such benchmarks should include: (1) minimizing overlap with other forms of intellectual property; (2) ensuring that the system is capable of stimulating results, and that those results are desirable; and (3) ensuring that there is a metric for measuring outcomes in relationship to goals.

In general, the goal of Regulatory Property can be described as promoting the development and commercial availability of safe and effective treatments. Framing

249. See Daniel et al., supra note 2; see also Joseph A. DiMasi \& Henry G. Grabowski, Economics of New Oncology Drug Development, 25 J. CLIN. ONCOLOGY 209 (2007) (noting that new oncology drugs have a disproportionately high share of FDA priority review ratings, orphan drug designations, and inclusion in expedited access programs). 
the goal in this manner explains, as well as dictates, various aspects of the design. In particular, the goal of safety and efficacy carries with it the need for certain types of value judgments that differ from other forms of intellectual property. Compare Regulatory Property with its cousins, patent and trade secret. The patent system does not care about how safe a drug is or how effective it is, only that its workings are different from what has come before and that there is some utility. ${ }^{250}$ The focus is on new, not on better or safer, and there is little awareness of the type of societal value judgments inherent in safety and efficacy. ${ }^{251}$

In fact, the pursuit of safety and efficacy values things that are the antithesis of newness. For example, a safety regime relies on the continued evaluation of patent experiences and adverse events in the life of the drug. Rather than simply pressing for new drugs and new treatments, safety considerations place value on more experience with and information about existing treatments.

Trade secret similarly lacks any focus on safety and efficacy. A trade secret must have value to be protected, but that value is contemplated in reference to conferring an advantage in the marketplace. ${ }^{252}$ One might hope that in a rational market, safety and efficacy would win out, but that is not necessarily true. If it were, there would be no need for the approval capacity of the FDA. Moreover, trade secret law values numerous categories of secrets unrelated to safety or efficacy, such as customer lists,

250. See Dennis S. Fernandez et al., The Interface of Patents with the Regulatory Drug Approval Process and How Resulting Interplay Can Affect Market Entry, in IPHANDBOOK OF BEST PRACTICES 965, 865-66 (Anatole Krattiger et al. eds. 2007), http://perma.cc/W8WS-UVET (noting that patents are granted to inventions that are "novel, useful, and nonobvious," and that the FDA is separately responsible for ensuring safety and efficacy); BRUCE LeHMAN, THE PHARMACEUTICAL INDUSTRY AND THE PATENT SYSTEM 7 (2003), http://perma.cc/8EWA-JAD7 (describing patent filing and FDA trials for safety and efficacy as two separate, distinct phases).

251. Courts have, on occasion in the distant past, denied patentability on the grounds that the invention was not "useful" for reasons of morality. The first articulation of this "moral utility" doctrine can be credited to Justice Story, who stated that "all that the law requires is that the invention should not be frivolous or injurious to the well-being, good policy, or sound morals of society. The word 'useful,' therefore, is incorporated into the act in contradistinction to mischievous or immoral." Lowell v. Lewis, 15 F. 1018, 1019 (C.C.D. Mass. 1817). See, e.g., Reliance Novelty Co. v. Dworzek, 80 F. 902, 904 (N.D. Cal. 1897) (striking down a patent for a slot machine cover due to lack of utility, based on assumed immorality of gambling); Nat'l Automatic Device Co. v. Lloyd, 40 F. 89, $89-90$ (N.D. III. 1889) (finding that an invention used only for gambling purposes is not a useful device, within the meaning of patent law); Rickard v. Du Bon, 103 F. 868, 873 (2d Cir. 1900) (invalidating patent used to defraud consumers into thinking domestic tobacco was expensive, imported tobacco); Mahler v. Animarium Co., 111 F. 530, 537 (8th Cir. 1901) (denying patent for medical device which claimed to use electricity to cure diseases, due to concerns about fraudulence). Modern courts, however, generally have avoided notions of morality in patentability decisions. See Margo A. Bagley, A Global Controversy: The Role of Morality in Biotechnology Patent Law, 320-23 (Univ. of Va. Law Sch. Pub. Law and Legal Theory Working Paper Series, Paper No. 57, 2007) (noting how in the late 20th century, courts began refusing to impose the moral utility requirement, viewing it as outside the purview of the judiciary); AMY L. LANDERS, UNDERSTANDING PATENT LAW $\$ 22.04$ ( $2 \mathrm{~d}$ ed. 2012) (noting the rarity with which moral utility is invoked today, and identifying the 1999 Federal Circuit decision in Juicy Whip, Inc. v. Orange Bang, Inc. as the basis).

252. Michelle L. Evans, Proof of Facts to Establish Information as Trade Secret Under Uniform Trade Secrets Act, 139 AM. JUR. PROOF OF FACTS 3d $241 \S 15$ (listing as a requirement to establish that certain information is trade secret, "information derives independent economic value, actual or potential from its secrecy"). 
sales techniques, and marketing strategies. ${ }^{253}$ These vie for attention in building the theoretical construct that encompasses trade secret law.

Thus, the goals of Regulatory Property can be understood as both broader and narrower than those for patent and trade secret. The goals are broader in the sense that with Regulatory Property, the focus is on issues generally not contemplated or not within the direct sights or even the peripheral vision of patent and trade secret laws. The goals are narrower in the sense that the development of safe and effective treatments is the sole focus, rather than any other marketplace advantage or any advancements unrelated to life sciences. This laser focus creates the potential for incentives that are far more particularized than intellectual property that must suit all types of innovation and serve all types of values.

Other value judgments lie embedded in the goal of safe and effective treatments. Medical treatment often involves tradeoffs that differ from other types of innovation. For example, the notion of safety is not an absolute value, and no treatment is 100 percent safe and effective for all patients in all circumstances. One must always determine what types of risks and side effects are acceptable to treat a particular disease state. This is not the quintessential patent or trade secret analysis.

An incentive structure keyed to safety and efficacy, along with real-time information and cost benefit analyses, must necessarily differ from the more familiar structures of other forms of intellectual property. To accommodate the agility required, such a system would need to be shorter, more flexible, and more targeted than patent and trade secret. And such is the general nature of Regulatory Property.

The greatest danger, however, lies where Regulatory Property overlaps with other intellectual property regimes, and it does so in the realm of innovation. Promoting the development of safe and effective treatments includes, of course, the notion of promoting development. Where the regimes rub shoulders against each other, there is a risk that each one's goals and limitations will conflict with the other or that both will get lost in the shuffle. This concern is reflected in the Congressional Research Service's observation that it makes little sense if, in the interests of promoting innovation, society denies patent rights to an invention that is too ordinary, but then grants similar protection in the context of drug testing. ${ }^{254}$ Different goals demand different types of incentive structures, not simply one tacked onto another.

Thus, Regulatory Property should not be a matter of granting an extra goody here and there. "Patents plus" or "trade secrets plus" is not a good logic for the regime of Regulatory Property. Nor should it be a way to tinker at the margins with something that dissatisfies a particular party or a way of getting a back-door patent. The benefit makes most sense when tethered to the goals of the system and aimed at incentivizing activity for which other intellectual property regimes are fundamentally ill-suited. There may be market failures, for example, which other regimes cannot address but for which Regulatory Property may provide a targeted solution. In short, frameworks that look like just an extension of another regime without all of the requirements are

253. RESTATEMENT (FIRST) OF TORTS $\S 757 \mathrm{cmt}$. b (AM. LAW INST. 1939) (stating that a trade secret may "relate to the sale of goods or to other operations in the business," including "a list of specialized customers").

254. See Thomas, supra note 32, at 13. 
more likely to be problematic. The goal should be as little overlap as possible.

Areas of overlap tend to create problems for intellectual property regimes, in general. They are a signal of unresolved difficulties, not a joyful combination or an intersection of ideals. One can think of them as analogous to "Rough Road Ahead" traffic signals. Consider patent and copyright protection for software; patent, copyright, and trademark protection for designs; and the ill-fated Semiconductor Chip Protection Act ("SCPA"), heralded with fanfare and then promptly ignored. ${ }^{255}$ Each of these marks an area of great and continued turmoil. ${ }^{256}$ Regulatory Property will be challenging as well. As difficult as navigating the boundary may be, however, success is critical if there is any hope of meeting the goals of each regime.

In addition to avoiding overlap with other intellectual property regimes, Regulatory Property should be evaluated in terms of whether the programs are capable of stimulating results and, most important, that those results are the ones we desire. Specifically, is society clear about its intended results, is the program stimulating those results, and is the program, nevertheless, creating intolerable externalities such that the program must be adjusted or abandoned? Consider, for example, the Regulatory Property granted for those who engage in pediatric studies. Creating incentives for companies to study the effects of medications in children has brought a wealth of important and sometimes unexpected knowledge about the effectiveness of treatments in that population. ${ }^{257}$ Nevertheless, scholars have

255. See Viva R. Moffat, Mutant Copyrights and Backdoor Patents: The Problem of Overlapping Intellectual Property Protection, 19 BerKeley TECH. L.J. 1473, 1518 (2004) (discussing problems resulting from overlap of design patents, and copyright and trademark for designs, patent/copyright overlap in software and in the SCPA); Gregory J. Maier, Software Protection-Integrating Patent, Copyright and Trade Secret Law, 69 J. PAT. TRADEMARK OFF. SOC'Y 151 (1987) (noting how the hybrid nature of software causes confusion in terms of how best to protect it); Pamela Samuelson, Digital Media and the Changing Face of Intellectual Property Law, 16 RUTGERS COMPUTER \& TECH. L.J. 323, 334 (1990) (noting how digital media, like software, created a new overlap between copyright and utility patent law); Stuart J. H. Graham \& David C. Mowery, Intellectual Property Protection in the U.S. Software Industry, in PATENTS IN THE KNOWLEDGE-BASED ECONOMY 219, 224-31 (2003) (analyzing the fluctuating relationship between copyright and patent protection for software); Leon Radomsky, Sixteen Years After the Passage of the Semiconductor Chip Protection Act: Is International Protection Working?, 15 BERKELEY TECH. L.J. 1049 (2000) (describing how the SCPA was largely obsolete soon after its passage and why it has been rarely invoked); Steven P. Kasch, The Semiconductor Chip Protection Act: Past, Present, and Future, 7 HiGH TECH. L.J. 71 (1992) (noting that despite substantial interest at the outset, the Act had generated only one published case eight years after its enactment).

256. See Adam Mossoff, A Brief History of Software Patents (And Why They're Valid) (Center for the Protection of Intellectual Property, Working Paper No. 14-41, 2013), http://perma.cc/BL25-DJWS (noting how debates about software patents today are "rife with extensive confusion and misinformation"); Justin M. Clark \& Julianne R. Davis, Pattern Overlay: Do Design Patents and Copyright Protection work with-or Against—Each Other?, 6 LANDSLIDE, no. 4, 2014, at 48 (2014) (describing how the recent Apple $v$. Samsung litigation highlights the dysfunctional overlap of design patents with other types of IP protection); Thomas Hoeren et al., Breakthrough Technologies-Semiconductor, Innovation, and Intellectual Property, 31-33 (WIP, Working Paper No. 27, 2015), http://perma.cc/32XT-Y2LB (describing continuing uncertainty in the IP landscape for semiconductors).

257. A Government Accountability Office ("GAO") Report found that $87 \%$ of drugs granted pediatric exclusivity under the BCPA underwent significant labeling changes as a result of the pediatric studies conducted. The labeling changes were generally necessitated by findings that children were being exposed to ineffective drugs, ineffective dosings, or previously unknown side effects. For instance, the drug Sumatriptan was being used to treat migraines in children, but studies conducted under pediatric 
questioned whether the rush to obtain this benefit has become a race-to-the-bottom in which commonly accepted scientific and ethical protocols are left in the dust. ${ }^{258}$

Any form of evaluation requires that there is some metric to examine in relationship to the goals. This means that the program itself should be able to articulate its aims in terms of metrics that can be repeatedly tested. It is not enough to articulate a general sense that additional benefits to particular types of actors will be good for particular health issues. Policy makers should identify both the result they intend and how they intend to measure progress toward that result. A system designed to be shorter and more nimble than other areas of intellectual property is particularly appropriate for evaluative metrics.

Most important, no evaluative measures are possible without transparency. Information on a range of issues, from pricing to the percentage of a drug's sales that are directed towards a desired usage, ${ }^{259}$ will be critical so that legislators and regulators can evaluate the effectiveness of programs on the ground.

The need for evaluation leads back, once again, to the notion that Regulatory Property must be conceptualized as a coherent whole. The appeal of understanding Regulatory Property as a unified system lies beyond the sublime beauty of logical consistency in theoretical constructs. From an instrumental perspective, understanding it as an integrated system is essential for evaluating the effectiveness of each of the programs individually and of the system as a whole. With these perspectives, society has an opportunity to think critically and cohesively about the new intellectual property that has spread its tendrils throughout health care innovation.

exclusivity found that children were having serious adverse reactions to Sumatriptan, including stroke and vision loss - the labeling was changed such that the drug is not recommended for children under 18 years old. See Marcia Cross, Pediatric Drug Research: Studies Conducted under Best Pharmaceuticals for Children Act, U.S. Gov'T ACCOUnTABILITY OfF., GAO-07-557, Pediatric Drug Research: STUdies Conducted under Best Pharmaceuticals For Children ACt 1, 18 (2007); see also Mike Mitka, FDA Alert on Antidepressants for Youth, 290 JAMA 2534 (2003) (discussing how FDA found a possible link between antidepressant drug treatment for pediatric patients and increased suicidal ideation and attempts, based on studies conducted under the pediatric exclusivity provision).

258. See Cohen, supra note 176, at 661.

259. See Daniel et al., supra note 2, at 4 (suggesting that orphan drug act reforms will require disclosure of percentage of sales that are for orphan conditions as opposed to non-orphan conditions). 


\section{APPENDIX A: SUMMARY CHART OF REGULATORY PROPERTY FORMS}

\begin{tabular}{|c|c|c|c|c|c|c|}
\hline Historical Context & Right for... & $\begin{array}{l}\text { Type of } \\
\text { Right } \\
\text { (Marketing, } \\
\text { Data, } \\
\text { Tradeable) } \\
\end{array}$ & $\begin{array}{l}\text { Length of } \\
\text { Right }\end{array}$ & $\begin{array}{l}\text { Similar } \\
\text { to... } \\
\text { (Patent, } \\
\text { Trade Secret, } \\
\text { Property) } \\
\end{array}$ & $\begin{array}{l}\text { Can add to } \\
\text { other } \\
\text { regulatory } \\
\text { rights }\end{array}$ & $\begin{array}{l}\text { Longer } \\
\text { than } \\
\text { stated } \\
\text { length** }\end{array}$ \\
\hline \multirow{4}{*}{$\begin{array}{l}1983 \text { Hatch- } \\
\text { Waxman Act \& } 1984 \\
\text { Orphan Drug Act } \\
\text { Amendments }\end{array}$} & First Generic Filers & Marketing & 6 months & Patent & N/A & No \\
\hline & New Chemical Entities & Data & $\begin{array}{l}5 \text { years or } 4 \\
\text { years* }\end{array}$ & $\begin{array}{l}\text { Trade } \\
\text { Secret }\end{array}$ & Yes & $\begin{array}{l}\text { Yes }(1-2 \\
\text { years) }\end{array}$ \\
\hline & New Clinical Studies & Data & 3 years & $\begin{array}{l}\text { Trade } \\
\text { Secret }\end{array}$ & Yes & No \\
\hline & Orphan Drugs & Marketing & 7 years & Patent & Yes & No \\
\hline \multirow{9}{*}{$\begin{array}{l}2011 \text { America } \\
\text { Invents Act \& } \\
\text { Biologics Act }\end{array}$} & First Biosimilar Filers & None & $\mathrm{N} / \mathrm{A}$ & $\mathrm{N} / \mathrm{A}$ & N/A & N/A \\
\hline & $\begin{array}{l}\text { First Interchangeable } \\
\text { Filers }\end{array}$ & Data & $\begin{array}{l}>12 \\
\text { months }\end{array}$ & $\begin{array}{l}\text { Trade } \\
\text { Secret }\end{array}$ & N/A & No \\
\hline & \multirow{2}{*}{$\begin{array}{l}\text { Original Biologic Drug } \\
\text { Makers }\end{array}$} & $\begin{array}{l}\text { Marketing } \\
* * *\end{array}$ & 4 years & Patent & Yes & No \\
\hline & & Data & 12 years & $\begin{array}{l}\text { Trade } \\
\text { Secret }\end{array}$ & Yes & No \\
\hline & $\begin{array}{l}\text { QDIP New Chemical } \\
\text { Entities }\end{array}$ & Data & $\begin{array}{l}+5 \text { years } \\
\text { (total } 9 \text { or } \\
10 \text { years) }\end{array}$ & $\begin{array}{l}\text { Trade } \\
\text { Secret }\end{array}$ & Yes & $\begin{array}{l}\text { Yes }(1-2 \\
\text { years })\end{array}$ \\
\hline & $\begin{array}{l}\text { QDIP New Clinical } \\
\text { Studies }\end{array}$ & Data & $\begin{array}{l}+5 \text { years } \\
\text { (total } 8 \\
\text { years) }\end{array}$ & $\begin{array}{l}\text { Trade } \\
\text { Secret }\end{array}$ & Yes & No \\
\hline & QDIP Orphan Drugs & Marketing & $\begin{array}{l}+5 \text { years } \\
\text { (total } 12 \\
\text { years) }\end{array}$ & Patent & Yes & No \\
\hline & Pediatric Studies & $\begin{array}{l}\text { Marketing, } \\
\text { Data }\end{array}$ & 6 months & $\begin{array}{l}\text { Patent, } \\
\text { Trade } \\
\text { Secret, } \\
\text { Property }\end{array}$ & Yes & $\begin{array}{l}\text { Depends } \\
* * * *\end{array}$ \\
\hline & Rare Pediatric Diseases & $\begin{array}{l}\text { Tradeable } \\
\text { (priority } \\
\text { voucher } \\
\text { review) }\end{array}$ & $\begin{array}{l}\text { FDA review } \\
\text { within } 6 \\
\text { months }\end{array}$ & Property & Yes & $\mathrm{N} / \mathrm{A}$ \\
\hline $\begin{array}{l}2007 \text { FDA } \\
\text { Amendment Acts }\end{array}$ & Tropical Diseases & $\begin{array}{l}\text { Tradeable } \\
\text { (priority } \\
\text { voucher } \\
\text { review) }\end{array}$ & $\begin{array}{l}\text { FDA review } \\
\text { within } 6 \\
\text { months }\end{array}$ & Property & Yes & N/A \\
\hline
\end{tabular}

*Length is shortened to four years if a generic hopeful files for FDA approval certifying its intent to challenge the patent on the drug as invalid, unenforceable, or not infringed

**FDA is not permitted to begin considering a generic hopeful until the right expires, so time until a generic enters is longer

***Designated as a marketing right in this chart because no follow-on company may apply

****Extension is added to prior regulatory right, so depends on nature of prior right 